\title{
The impact of negative word of mouth and rumors on customer-brand relationship through the mediating effect of brand trust: Applied study on Egyptian laboratories
}

\author{
Prepared 6y \\ Dr. Sherif Taher \\ Mohammed Farid \\ Sadat Academy for Management

\section{Dr. Sara Abd-EI Fattah Hammad} \\ Sadat Academy for Management
}

Sciences, Faculty of business, Egypt

Sherif-taher@hotmail.com
Sciences, Faculty of business, Egypt

shammad2005@yahoo.com

Scientific Journal for Financial and Commercial Studies and Researches (SIFCSR)

Faculty of Commerce - Damietta University

Vol.3, No.1, Part 1., January 2022

APA Citation:

Farid, S. T.M. and Hammad, S. A. (2022). The impact of negative word of mouth and rumors on customer-brand relationship through the mediating effect of brand trust: Applied study on Egyptian laboratories, Scientific Journal for Financial and Commercial Studies and Research, Faculty of Commerce, Damietta University, 3(1)1.pp. 153-204

Website: https://cfdj.journals.ekb.eg/ 
Scientific Journal for Financial and Commercial Studies and Researches

(SJFCSR) Faculty of Commerce - Damietta University

\title{
The impact of negative word of mouth and rumors on customer-brand relationship through the mediating effect of brand trust: Applied study on Egyptian laboratories
}

\author{
Dr. Sherif Taher Mohammed Farid
}

Dr. Sara Abd-El Fattah Hammad

\begin{abstract}
:
Purpose - The most important challenge for the Egyptian laboratories is to enhance their relationship with the customers and to increase their brand trust. Nowadays, marketers try to avoid the negative impact of NWOM and rumors on the customer behaviour and many investigations are done to avoid such outcome. The emerging of the social media helps customers to learn more and share information and interact with each other as such platforms are a dominant digital communication channel.
\end{abstract}

The purpose of this research is to measure the effect of NWOM and rumors on the relationship between the customer and the brand using this mediating variable (brand trust) to give satisfaction and to reduce the negative effect of NWOM and rumors.

Design/methodology/approach - The design of this research is descriptive and quantitative, primary data were collected through the EQuestionnaire method introduced by Google forms for applying the questionnaire through the Internet and filling it out by different respondents. Data were gathered from 340 laboratories customers. Hypotheses were tested using the statistical package for social sciences (SPSS V26) for basic descriptive statistics, and (Smart PLS 3.2.7) for SEM-PLS modelling.

Findings - The results revealed that when using brand trust (BT) as a mediating variable, a significant negative impact on the customer brand relationship (Commitment, Intimacy and Interdependence) was found with respect to NWOM whether directly or indirectly but surprisingly 


\section{Dr. Sherif Taher Mohammed \& Dr. Sara Abd-El Fattah}

rumours do not have such effect directly but have a weak negative indirect effect. The brand trust mediator the relationship between NWOM and the customer brand relationship. Also, from the interesting findings where that there is a significant relationship between independent variable and the mediator (BT).

Originality/value - This research examines empirically the effect of online/offline NWOM and rumours on the relationship between Egyptian customers and laboratories. Theoretical and practical implications are discussed for researchers, practitioners and marketers to use effective and efficient marketing strategies to reduce the negative impact of NWOM and rumours and to increase brand trust in customers' mind and so decreasing the negative impact of independent variables.

Keywords: Negative word of mouth, Rumours, Brand trust, customerbrand relationship, laboratories.

\section{1. introduction:}

The spread of the pandemic coronavirus disease 2019 (COVID 19) has resulted in many misinformation regarding the outcomes, prevention and cure of such virus causing countless rumors and eventually resulting in unhealthy mental and physical consequences among individuals and the misfortunate in accurate practices. Not only health systems worldwide were provoked to provide contemporary research findings and precise information to satisfy individuals but also marketers should formulate marketing strategies to avoid the negative effect of commercial rumors (online/offline) on the customer-brand relationship and to rebuild trust between customers and the laboratories fields. Brand managers and the laboratory representatives should not neglect the crucial and pivotal impact of NWOM on the brand image and the relationship between customers and laboratories as confirmed by (Tasnim, Hossain, and Mazumder, 2020).

According to (Kemp, Jillapalli and Becerra, 2014), healthcare is the most important yet personalized service presented to customers. As more healthcare alternatives become available to consumers, more competition will exist within the industry. According to (Shabbir, Kaufmann, and 
Scientific Journal for Financial and Commercial Studies and Researches (SJFCSR) Faculty of Commerce - Damietta University

Shedzad, 2010) the success of healthcare organizations depends on the patients' satisfaction which can be achieved by providing better healthcare services; keeping in view the patient's expectation and continuous service improvement of the healthcare.

According to (Tasnim, Hossain, and Mazumder, 2020) diffusing responsible public health messages should be provided by the healthcare institution, mass media, community organizations, and other dominant stakeholders were strategic partnerships and common policies should be constructed. Through advanced technologies like natural language processing or data mining applications the detection and removal of any online content (of no scientific basis) should be erased from all social media platforms. Moreover, these practices should be overseen with law enforcement measures and regulations in addition to ensuring telemedicine services providing accurate instructions on (COVID-19).

Because of the rapid interaction among peers, commercial rumours about a brand or an organization, particularly on social media grands a distinct challenge for communication practitioners and marketers. In spite of the importance of refuting rumours quickly and effectively, research on this field is limited. To advance the literature in this emerging research area, the current paper examines the impact of NWOM and rumours on customer-brand relationships thus providing functional, psychological, social and emotional benefits.

In healthcare industry, both online and offline NWOM and rumours can negatively affect brand trust in customer's mind. In developed and developing countries a lot of consumers have lost their trust regarding the healthcare and laboratories services. The importance of laboratories services is nowadays recognized due to the great concern of people worldwide about the pandemic COVID-19. As healthcare decisions are highly personal and it has a high impact on the patients' lives because it ranges from basic quality of life to literally, life-or-death situation service sector. (Hopkins, 2017) Therefore, trust plays a major role in consumer decision-making toward healthcare and laboratories services so developing a strong brand which can put the laboratories ahead of the vast majority of their competition. 


\section{Dr. Sherif Taher Mohammed \& Dr. Sara Abd-El Fattah}

According to (Zubiaga, 2015; Chen 2016) the objective of this publication of the negative word of mouth (NWOM) and rumours depends on the objectives of their promoters and their ideas. In some cases, whether commercial so as to seek an excess demand for a certain service as a marketing technique, or competitive in some other cases to confuse a competing brand by distorting the facts, or fabricating an untrue story. Additionally, researchers (Kalamas, Laroche, \& Makdessian, 2008; Soscia, 2007; Wetzer et al., 2007) have reached that firm's negative performance can lead eventually to negative emotional reaction that leads to NWOM (social and personal characteristics, uniqueness, social ties and negative emotions) can all influence customers to believe NWOM resulting from dissatisfactory consumption experience according to (Schlosser, 2005; Alexandrov, Lilly, \& Babakus, 2013; Zhang et al., 2013 and Alexandrov et al., 2013)

Thus, it is difficult to affirm to what extent NWOM and rumours in social network sites affect the laboratory service and to what extent it can influence the use of such laboratories by the customer. Therefore, the current research problem discusses the measurement of the negative impact of NWOM and rumours on the interrelation between customers and Egyptian laboratories and determining to what extent laboratories are influenced by such NWOM and rumours.

Through examination and analysis, this problem raises a series of questions that can provide clear and accurate answers as follows:

- What is the impact of NWOM and rumours on the relationship between laboratories and their customers?

- What is the level of customer trust in the service quality of Egyptian laboratories?

- Is there a difference in the effect of NWOM and rumours on the customer-brand relationship, depending on the level of customers' brand trust?

- What is the mediating effect of brand trust in the relationship between rumours and NWOM and customer-brand relationship?

The purpose of this research is to investigate the impact of brand trust in the relationship between NWOM and rumours and the customer- 
brand relationship. Thus, the study is done from the consumer point of view. From the academic aspect of the study problem there is a research gap represented in the lack of Arab studies in measuring the relationship among the variables of the study combined made a research gap that the current study attempts to remedy by providing an extended understanding of the Egyptian customer's response to NWOM and rumours, especially in laboratories field. Furthermore, The Egyptian laboratories can benefit from this study to improve their ability to deal with NWOM and rumours in general and to use marketing strategies to build a brand trust which reduces the negative impact of NWOM and rumours.

\section{2- Literature Review:}

\subsection{Negative word of mouth (NWOM):}

Online and offline word-of-mouth (WOM) has a powerful influence on a consumer's behaviour where an informal advice with no commercial bias can be passed between consumers (East et al., 2008).

A former or an actual consumer via the internet to any person or an organization about a product or a service can cause a very persuasive market (Hennig $\square$ Thurau, Gwinner, Walsh, \& Gremler, 2004). This online word-of-mouth may be positive or negative advertisement. If positive; it can be beneficial and if negative; it can be more powerful in its effect causing disaster and destruction (Bayus, 1985; Richins, 1983; Schiffman \& Kanuk, 1991). Social media is important in our lives, preventing others from adopting certain service and can damage the brand image of a company as there is less control over the media (Thomas et al., 2012). The positive word-of-mouth (PWOM) has less impact than (NWOM) because the NWOM persists even when denied (Weinberger et al., 1981). In case of service, every time period the customer reviews the service and are often heterogeneous although the dissatisfaction of the customers may have a powerful effect on such service and can be the cause for its termination (Richins, 1983; Anderson, 1998; Chan \&Cui, 2011).

The negative word-of-mouth is destructive when transmitted to consumers and is unconfirmed, it is then called rumours. Unlike electronic word-of-mouth which is more convenient when information is shared anytime, anyplace with others (Sun, Youn, Wu, \& Kuntaraporn, 


\section{Dr. Sherif Taher Mohammed \& Dr. Sara Abd-El Fattah}

2006). The online and offline negative word-of-mouth (NWOM) is the dissatisfaction of the consumer which can be due to social ties, uniqueness or other social characteristics (Richins, 1984; Kamins, Folkes, \& Perner, 1997, Schlosser, 2005; Alexandrov, Lilly, \& Babakus, 2013; Zhang et al., 2013; Berger, 2014 and Septianto, F., Northey, G., Chiew, T.M., Viet Ngo, L., 2019). This concurs with the current study which found that $63 \%$ of the respondents' choices are affected by NWOM.

The authors (Sweeney, Soutar and Mazzarol, 2005) demonstrate that NWOM is more influential that PWOM being more emotional and usually provoked by the dissatisfaction of the receiver's opinion. These consumers tend to vent their anger through NWOM even sooner than those having PWOM.

As (Audrain-Pontevia and Kimmel's, 2008) shows the companies managers have two strategies which may counteract the NWOM; either by increasing trust in service/ product or by the denial of the NWOM through an official from the company or an outside source by the organization so better attention and management is paid to the NWOM than to PWOM promotion (Williams and Buttle's, 2014). These authors recommended three steps to manage NWOM; (a) leadership management, (b) readiness of the organization, (c) management of the public relation.

According to (Bachleda and Berrada-Fathi, 2014 and Beneke, de Sousa, Mbuyu and Wickham, 2015 and Chiosa and Anastasiei, 2017) NWOM may be from review sites, from friends and relatives or on website of competitors. These negative testimonials may affect negatively the buying intentions of the customers toward any service or product, and may even damage or have an adverse effect significantly on the brand trust. The authors therefore suggest the complains made by consumers should be done directly to the company's website instead of the negative reviews on the social media.

These negative comments particularly made by customers not only have more persuasive reviews than positive reviews (Bae, Lee 2011a; Jeong, Jang 2011and Muneta, 2017) but also have a negative effect on brand image and on the customer-brand relationship. $77 \%$ of the current 
Scientific Journal for Financial and Commercial Studies and Researches (SJFCSR) Faculty of Commerce - Damietta University

survey respondents' (descriptive results) where interested in reviewing positive and negative comments of other customers and $68 \%$ of respondents are keen to comment and share their positive or negative experience on social networks when dealing with the laboratories.

According to (Gheorghe, Liao 2012), the linguistic impact is greater on users giving negative electronic word-of-mouth due to anger or dissatisfaction of the service. Opposing this opinion, (Kim, Gupta 2012) believe that these emotions although negative tend to have less influence than is expected because consumers know that these expressions can be due to frustration and irrational disposition. Hence, the following hypotheses are formed.

H1: NNWOM has statistically significant negative effect on customerbrand relationship

H1a: NNWOM has statistically significant negative effect on customer commitment

H1b: NNWOM has statistically significant negative effect on customer intimacy

H1c: NNWOM has statistically significant negative effect on customer Interdependence

H3: NNWOM has statistically significant negative effect on brand trust

\subsection{Online and Offline Rumours:}

When information is distorted, irrational or overstated then it is defined as rumours (Miller 1992 and 2007; Fine et al. 2005). According to (Peterson and Gist 1951; Liu, 2014), the rumours can be defined as unconfirmed verification from the message receiver or the anti-social communication for a good or service of public interest.

Other authors as (Rosnow, 1991; Vosoughi, 2015; YANG \& WU, 2016) described rumours as the negative statement wide spread by public communication without official confirmation which might later prove true or false (Liu 2014). Similarly, (Amoozgar, Ramezanian ,2104) agreed that the disseminating uncontrolled negative statements are the main characteristics of a rumour. 


\section{Dr. Sherif Taher Mohammed \& Dr. Sara Abd-El Fattah}

The wide spreading of a rumour is usually done to slander others, attract attention, increase awareness or to cause panic although the spread by WOM usually has a limited impact (Zhang \& Watts, 2004, Kosfeld, 2005). This coincides with our current study which found that the wide spreading of social media rumours has limited impact on Egyptian customers when using laboratories services $(61 \%)$ of respondents. Additionally, $74 \%$ of respondents mention that their evaluation for the service quality provided by the laboratories under study is not affected by either rumours on social networks or oral offline rumours.

Media rumours defined as unconfirmed events given by one or more customer either spontaneous or artificial and broadcasted through communication technology either orally or written through mass media means until official denial or conformation. Rumours can be due to problematic or emotional statements resulting in collective creation and attempts to explain it (Borodina \& Zheltukhina, 2013; 2015a; 2015b). However, (Bordia et al. 2006) confirmed that rumours are either positive or negative.

Opinions nowadays are shared freely through social media or through thousands of blogs without constrains (time or space). In the past, rumours were transmitted by WOM through online communication but it took a small share, nowadays communications and rumour spreading have changed from hearing to seeing and written or by voice messages which can be easily transmitted through Twitter, Facebook, and YouTube. The authgors (Bordia et al. 2005; DiFonzo and Bordia 2007; Rosnow and Kimmel 2000) confirmed that the common most spread definition of rumour is that it is unconfirmed and uncertain WOM about personal current events but important and informative for individuals interested in the dissemination of such rumours. The spreading of rumours on the web can be labelled as internet rumours (negative eWOM) opinions of reviews of a product can be posted by communication through internet on different channels as web blogs, review websites (e.g.tripadvisor.com), e-bulletin board systems (BBS), newsgroups, social networking sites (e.g.facebook.com) and through e-mail. Hence, the following hypotheses are formed. 
Scientific Journal for Financial and Commercial Studies and Researches (SJFCSR) Faculty of Commerce - Damietta University

H2: Rumours has statistically significant negative effect on customerbrand relationship

H2a: Rumours has statistically significant negative effect on customer commitment

H2b: Rumours has statistically significant negative effect on customer intimacy

H2c: Rumours has statistically significant negative effect on customer Interdependence

H4: Rumours has statistically significant negative effect on brand trust

\subsection{Brand Trust (BT):}

Researchers (Erdem \& Swait, 2004; Agustin and Singh, 2005; Sahin et al.2011; Choi 2012 and Azizea, Cemalb and Hakanb, 2012) all have agreed on the definition regarding trust in any brand where the consumers belief that their favourite chosen brand will deliver benefit, credibility, integrity and promising service for them. They have agreed as well that trust should provide benefits for the value of money that the customer pay for as it will encourage them to repeat the purchase from this chosen brand. When trust is found in any brand name with high levels; it can reflect in reducing the risk and help in duplicating favouritism toward the brand as consumers believe that services from either health care organizations or laboratories as in our current study should provide specific features which are consistent, reliable, and credible with the consumers expectations according to (Ballester, Aleman, Guillen, 2003; Kumar, Advani, 2005; El Naggar RAA, Bendary N., 2017 and Shin, Amenuvor, Basilisco, and Antwi, 2019).

A successful brand trust relationship between any company with a brand name and its customers is achieved through mutual experiences and activities (Anderson \& Narus, 1990). There have been several conceptualizations of brand trust in the extent branding literature. Researchers as (Chaudhuri A, Holbrook MB, 2001; Delgado-ballester et al., 2003 and Shin, Amenuvor, Basilisco, and Antwi, 2019 Dalziel N, Harris F, Laing A) have reached that brand trust is the state in which the consumers feel they can rely on the brand name to provide them with the 


\section{Dr. Sherif Taher Mohammed \& Dr. Sara Abd-El Fattah}

feeling of being secure and to provide them with reasons for being dependent on their brand because of its ability to satisfy its customers and fulfil their promises.

Therefore, customer trust towards any brand name is extremely important as it is related directly to the communication and satisfaction regarding the good or service especially laboratories services according to (Doney, and Cannon, 1997; Azizea, Cemalb and Hakanb, 2012 and Shin, Amenuvor, Basilisco, and Antwi, 2019). Furthermore, brand trust can act as an intermediate for brand loyalty when long-term relationships are developed through satisfactory former experiences between brand name and its consumers (Krishnan, 1996; Lewis and Soureli, 2006; Ndubisi, 2007; El Naggar and Bendary, 2017 and Shin, Amenuvor, Basilisco, and Antwi, 2019).

(Garbine and Johnson,1999) suggested that the consequence of brand trust can be achieved from previous experiences and interchanges and reflects the procedure of learning over time. This is consistent with the descriptive results of the current study which illustrated that $88 \%$ of respondents who build their trust depending on the level of constantly of laboratories service quality and that $57 \%$ of respondents want to defend the laboratory it deals with against any false news or rumours and seeks support through a positive WOM.

According to (Chaudhuri and Holbrook, 2001; Delgado-Ballester et al. 2003; Reast, 2005; and Luk and Yip, 2008 and Shin, Amenuvor, Basilisco, and Antwi, 2019) they have found that brand trust has multiple aspects, which could include reliability, credibility, safety, honesty, performance satisfaction, benevolence and brand intentions.

(Shin, Amenuvor, Basilisco, and Antwi, 2019) defined brand reliability as the consumer's belief that the brand achieves its value as promised, while (Ameri and Behnam, 2014 and Shin, Amenuvor, Basilisco, and Antwi, 2019) defined brand credibility as the brand's ability to meet the terms of exchange respective to expected performance. Others as (Cambier, Poncin, 2018) suggest that brand integrity as customers' dependency on the brand name and use them as a basis for making product choices, magnifying their trust in the brand. While brand benevolence is defined as the sustaining of a long-lasting customers to 
Scientific Journal for Financial and Commercial Studies and Researches (SJFCSR) Faculty of Commerce - Damietta University

their brand and simultaneously taking into account the consumer interest (Gurviez P, Korchia M., 2003; Foroudi, 2019 and and Shin, Amenuvor, Basilisco, and Antwi, 2019). According to (El Naggar and Bendary, 2017 and Shin, Amenuvor, Basilisco, and Antwi, 2019) brand trust can be built first through developing emotional trust by providing evidence that their brand can and is able to meet the expectations of the consumers and second; customers who evaluate the information about the product or service to make sure that it is reliable and credible.

So, finally we can deduce that brand trust is the main success factor in any customer-brand relationship marketing which includes service quality, loyalty, satisfaction, and communication between brand name and the customers also includes the amount of cooperation provided to consumers to help in maintaining the ongoing process of building trust of the brand name (Parasuraman et al., 1985; Morgan and Hunt, 1994; Azize, Cemal and Hakan, 2012 and Ahmed, 2014). Hence, the following hypotheses are formed.

H5: Brand trust has statistically significant effect on customer-brand relationship

H5a: Brand trust has statistically significant effect on customer commitment

H5b: Brand trust has statistically significant effect on customer intimacy

H5c: Brand trust has statistically significant effect on customer Interdependence

H6. Brand trust mediates the relationship between NWOM and customer-brand relationship (Commitment, Intimacy and Interdependence)

H7. Brand trust mediates the relationship between Rumours and customer-brand relationship (Commitment, Intimacy and Interdependence) 


\section{Dr. Sherif Taher Mohammed \& Dr. Sara Abd-El Fattah}

\subsection{Customer-Brand Relationship (CBR):}

The researchers (Blackston, 2000; McAlexander, Schouten, \& Koening, 2002 and Chang \& Chieng, 2006) have defined brand relationship as the connection between a person and a brand name services that is done either voluntary; when the relationship is intimate and personal or enforced depending on both customers and brand name attitudes (Coelho et al., 2018). In addition, customer-brand relationship is developed over time due to the customers' prior and various experiences and process with any brand name (Bowden, 2009; MacInnis et al. 2009). That is done inter-dependtly to help in developing better brand experience and creating brand equity and enhancing customers' feelings towards the brand (Veloutsou, 2007). While (Keller, 2001; Kumar, 2006 and Blackston and Lebar, 2015) focused on building brand relationships through long-term commitment with the products or service that consumers use, buy, sell or distribute.

Customer-brand relationship nature is interpersonal as it can act as a metaphor of marketing between brand and customers depending on emotions and rational behaviours. (Aggarwal, 2004; Charton-Vachet and Lombart, 2018). Researchers (Fournier, 1998 and Smit et al. 2007) suggests that strong brand relationship with customers is important as it helps in lessening the costs of marketing, intensifying customer reachability to the brand and obtaining new customers and consequently leading to brand equity and customer loyalty being increased.

Regarding business relationships, when the market is highly competitive, then it requires marketers of brand names to figure out ways to help in maintaining a long-term brand relationship with their consumers. Brand relationship is essential in the service sector as in our current study which is the laboratories in the health care sector because of its intangible characteristics as it is hard for customers to visually evaluate the services presented to them. Therefore, the success of brand relationship is based on the good quality of the service provided and the acquiried knowledge about customers wants and which brand is highly preferable to them which consequently will lead to brand loyalty and brand trust (Hennigthurau, Gwinner \& Gremler, 2002; Loureiro, 2015 and Prihandoko, 2016). 
Scientific Journal for Financial and Commercial Studies and Researches (SJFCSR) Faculty of Commerce - Damietta University

In addition, researcher (Fournier, 2009) suggests that brand relationships with customers need to take into consideration (1) the benefits presented to customers to satisfy their wants and needs, (2) the strength of relationship between customer and brand depending on the types of different relationships, and (3) the development of the brand relationship with the customers.

(Fouriner, 2009 and Fouriner and Avery, 2011) found that brand relationship strength can vary from weak to strong and brand relationship rewards can vary from socio-affective to functional.

Lately, (Fournier, 1998; Leung et al., 2014; Loureiro, 2015 and Ghani and Tuhin, 2016) have evaluated brand relationship strength, steadiness and constancy through brand relationship quality dimensions which are; self-connection, love and passion, interdependence which falls under (affective dimension) and commitment, intimacy and brand partner quality which falls under (utilitarian dimension). Furthermore, (Fritz and Lorenz, 2010 and Ghani and Tuhin, 2016) added that they found that there are 9 dimensions in measuring brand relationship with customers which are: (1) Intimacy; (2) Interdependence; (3) Equity; (4) Brand trust; (5) Passion; (6) Satisfaction; (7) Brand commitment; (8) Actual behaviour; and, (9) Relationship duration.

Finally, customer-brand relationship is becoming important from the point of view of marketers' managers due to its influence on the thinking of consumers about their brand names and the ability to drive consumers to differentiate their brands from any other brand (Ghani and Tuhin, 2016 and Leung, 2016).

In this current study, the researchers will shed the light on brand commitment, brand intimacy and brand interdependency.

\subsubsection{Brand Commitment:}

The commitment of a consumer means his/her future want to remain in a relation with a certain brand (Suh and Han, 2003 and Albert, and Merunka, 2013, and Loureiro, 2015). Some brands give the warmth and joy to the consumer and so a sustained bond is formed. The higher commitment to a brand gives a stronger attachment to this brand (Keh et al., 2007). 


\section{Dr. Sherif Taher Mohammed \& Dr. Sara Abd-El Fattah}

Commitment can be either (a) affective that is to say strong emotional attachment to the brand with personal identifications or values (Pring, 2007) or (b) continuous that is to say weak attachment to the brands where consumers can easily switch from one brand to the other due to cost (c) finding alternative brands (Fullerton, 2003) which can be harmful where the unwillingness of the consumers to engage in advocacy intentions appear (Erics, Unal, Candan, Yildirim 2012).

\subsubsection{Brand intimacy:}

When a brand interacts with the consumer psychologically, this can be defined as brand intimacy. In a general sense, online marketing indicates the closeness of the individual to online communication with similar users. This aids brands to help, manage and better measure attachment to consumers (Thorbjørnsen et al.2002), thus inspiring more profit and building up a brand name through a social presence on different media according to (Kumar and Benbasat 2002; Wang et al. 2007).

Brand intimacy indicates the self-presentation and language of the brand on social media, kit can be (a) through named employees addressing customers (informal approach) thus giving a level of intimacy between the brand and the customer which influence the purchase and affect their attitudes towards this brand or can be (b) through the impersonalized brand presentation (formal approach); this distant approach influences customers perceptions about certain brands indicating its superiority and irreplaceability (Loureiro, 2015 and Barcelos , Dantas , Sénécal , and Rossi, 2016).

Brand intimacy analysis indicated a relation between the brand and the customer giving it an emotional attachment to build up a long-term relationship purchase of the brand, consequently creating an ascending intimacy and trust with consumers. According to (Luca Petruzzellis et al. 2016; Richard Rosenbaum-Elliott et al. 2015; V. Kumar,2008) there are three levels to the brand relationship customer (a) sharing, (b) bonding, (c) fusing. 
Scientific Journal for Financial and Commercial Studies and Researches

(SJFCSR) Faculty of Commerce - Damietta University

\subsubsection{Brand Interdependence:}

Interaction between partners and the strength of occurance of each through their scope activities are important factors of brand quality relationship. So, the brand independence to a great degree depends on the action and the reaction of the partners indicating an intwined relationship (Thorgjornsen, Supphellen, Nysveen and Pedersen, 2002).

However, interdependence by (Loureiro, 2015) has defined this term as associated to a strong brand activities relationship involving frequent brand interactions. Finally, interdependence involves regular interactions between the brand and the customer, (a) increasing scope, (b) increasing intensity of personal experiences, and (c) affecting the diversity of brand-related actions. The research model is shown in Figure 1

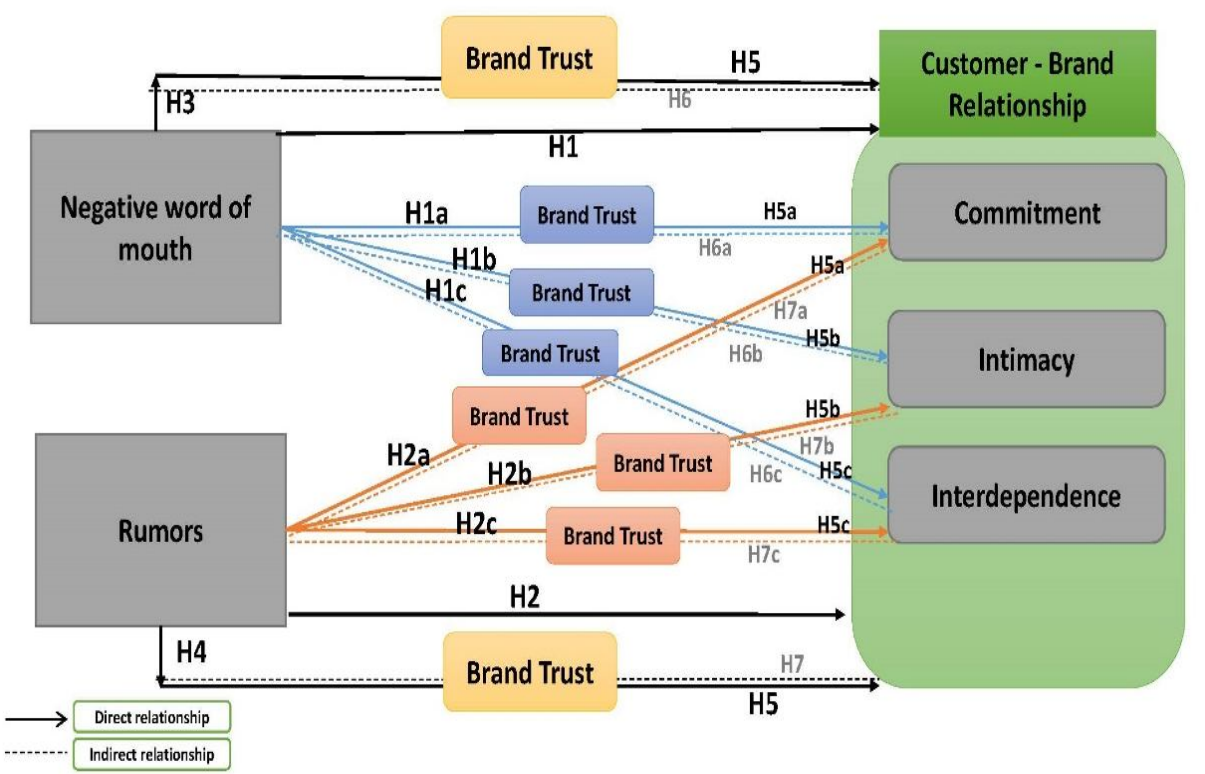

Figure 1 Conceptual diagram explaining the Research Model 


\section{Dr. Sherif Taher Mohammed \& Dr. Sara Abd-El Fattah}

\section{3- Research Methodology}

The present study is mainly built on the analytical descriptive method that involves library surveying by reference to former research, for constructing a theoretical basis for the conducted study, using some qualitative research approaches along with the field survey scheme for collecting data by applying a targeted survey.

\subsection{Data Collection and Sample}

In this research, the survey questionnaire approach was utilized for collecting data via the post-positive lens for model testing. The present study, thus, employed non-probability sampling, precisely, the purposive sampling procedure. To incorporate the technique of the purposive sampling into the process of collecting data, the respondents were required to use, at minimum, laboratories' services in addition to the study was limited to Egyptian customers during the study period.

Owing to the customer population's large size, the time factor, and cost considerations, which act as restraints in research, the sampling method was chosen for collecting data needed for the consumer field study. The sample size was verified and estimated at 384 individuals, following the act of large numbers.

Data collection was done using the E-Questioner method presented by Google forms for applying the questionnaire through the internet . To measure each attitude item, a five-point Likert-scale that ranges from strongly disagree (1) till strongly agree (5) was utilized. We collected 345 responses, 340 of which were retained for analysis. The data collection process lasted approximately (3) months from Jan. 2021 to Mar. 2021. Data analysis was carried out using SPSS and the Smart-PLS 3.2.7 software.

\subsection{Measures:}

To test this study model, the technique of Partial Least Squares (PLS) was applied, using the Smart-PLS 3.2.7 software (Ringle, Wende, $\&$ Becker, 2015). A two-stage analytical procedure was followed as recommended by reflective constructs (Anderson \& Gerbing, 1988; Ramayah, Lee, \& In, 2011). Accordingly, the measurement model test (constructs' validity and reliability) was conducted, followed by an 
Scientific Journal for Financial and Commercial Studies and Researches (SJFCSR) Faculty of Commerce - Damietta University

investigation of the structural model (testing of the hypotheses) (Ramayah, Jasmine, Ahmad, Halim, \& Rahman, 2017). A bootstrapping technique was utilized to test the path coefficients' significance and for the loadings (Hair, Hult, Ringle, \& Sarstedt, 2017).

To obtain the measurement of involved variables and the number of items, some previous studies are considered as shown in Table (1). The study included three kinds of variables, NWOM and rumours (independent variables), customer-brand relationship (dependent variable), brand trust (mediating variable). The items and questions used were constructed and refined centred on literature and the responses were measured on a five-point Likert-scale.

Table (1) The measures are used in the study

\begin{tabular}{|c|c|c|}
\hline Variable & $\begin{array}{l}\text { Number } \\
\text { of items }\end{array}$ & Reference \\
\hline NWOM & 4 & $\begin{array}{l}\text { (Audrain-Pontevia and Kimmel's, 2008: } \\
\text { Williams and Buttle's, 2014; Bachleda and } \\
\text { Berrada-Fathi, 2014; Beneke, de Sousa, Mbuyu } \\
\text { and Wickham, 2015; Chiosa and Anastasiei, } \\
\text { 2017) }\end{array}$ \\
\hline Rumours & 3 & $\begin{array}{l}\text { (Fine et al. 2005; Vosoughi, 2015; Yang \& Wu, } \\
\text { 2016) }\end{array}$ \\
\hline Brand Trust & 9 & $\begin{array}{l}\text { (El Naggar RAA, Bendary N., 2017; Shin, } \\
\text { Amenuvor, Basilisco, and Antwi, 2019) }\end{array}$ \\
\hline $\begin{array}{c}\text { Customer-brand } \\
\text { relationship }\end{array}$ & 9 & $\begin{array}{l}\text { (Kumar, 2006; Blackston and Lebar, 2015; } \\
\text { Charton-Vachet and Lombart, 2018) }\end{array}$ \\
\hline commitment & 3 & (Albert, and Merunka, 2013; Loureiro, 2015) \\
\hline intimacy & 3 & $\begin{array}{l}\text { (Loureiro, } 2015 \text { and Barcelos, Dantas, Sénécal, } \\
\text { and Rossi, 2016) }\end{array}$ \\
\hline interdependence & 3 & $\begin{array}{l}\text { (Thorgjornsen, Supphellen, Nysveen and } \\
\text { Pedersen, 2002; Loureiro, 2015) }\end{array}$ \\
\hline
\end{tabular}

\section{4- Results and Findings:}

This part presents the data analysis part of this paper. The analysis of this paper was done using the statistical package for social sciences (SPSS V. 26) for basic descriptive statistics, and (SmartPLS 3.2.7) for 


\section{Dr. Sherif Taher Mohammed \& Dr. Sara Abd-El Fattah}

SEM-PLS modeling. The first section deals demographic characteristics. The second section provides the data preparation procedures. The measurement model was evaluated for the reliability and validity of the instruments in section three. Several descriptive statistics and bivariate correlations are constructed in section four. Subsequently, the structural model for testing mediator variable was constructed in section five.

\subsection{Respondents' Demographics:}

Table (2): Characteristics of respondents' demographics

\begin{tabular}{|c|c|c|c|}
\hline Variable & Category & Frequency & $\%$ \\
\hline \multirow{2}{*}{ Gender } & Male & 166 & $50.5 \%$ \\
\hline & Female & 163 & $49.5 \%$ \\
\hline \multirow{4}{*}{ Income } & $1000-5000$ & 148 & $51.9 \%$ \\
\hline & $5000-10000$ & 75 & $26.3 \%$ \\
\hline & $10000-15000$ & 41 & $14.4 \%$ \\
\hline & Other & 21 & $7.4 \%$ \\
\hline \multirow{4}{*}{ Age } & $20-30$ & 205 & $61.7 \%$ \\
\hline & $31-40$ & 52 & $15.7 \%$ \\
\hline & $41-50$ & 42 & $12.7 \%$ \\
\hline & More than 50 & 33 & $9.9 \%$ \\
\hline \multirow{3}{*}{ Marital Status } & Single & 208 & $63.4 \%$ \\
\hline & Married & 117 & $35.7 \%$ \\
\hline & Other & 3 & $0.9 \%$ \\
\hline \multirow{6}{*}{ Lab } & Alpha Lab & 144 & $44.3 \%$ \\
\hline & AlMokhtabar Lab & 95 & $29.2 \%$ \\
\hline & AlBorg Lab & 62 & $19.1 \%$ \\
\hline & ALSHAMS Lab & 4 & $1.2 \%$ \\
\hline & Saridar Lab & 4 & $1.2 \%$ \\
\hline & Other & 16 & $4.9 \%$ \\
\hline
\end{tabular}

The demographic characteristics of respondents were reported in table (2). It can be noticed that males were (166) with $50.5 \%$ of the sample, while females were (163) with $49.5 \%$ of the sample. About $52 \%$ of the sample has income between (1000) and (5000), 26\% have income between (5000) and (10000), 14\% have income between (10000) and (15000), and 7\% have income other than that. Most of respondent's ages 
were between 20 and 30 by almost $62 \%$, while $16 \%$ were between 31 and 40 years old, 13\% were between 41 and 50 years old, and finally, 10\% have ages more than 50 years old. Between the respondents, there were singles by $63 \%$, married by about $36 \%$, and others by $1 \%$. About $44 \%$ of the respondents dealing with Alpha Lab, 29\% dealing with AlMokhtabar Lab, 19\% dealing with AlBorg Lab, 1.2\% for both ALSHAMS Lab and Saridar Lab, and 5\% for other labs.

\subsection{Data Examination:}

The issues of collected data, including missing data, outliers, and common method bias (CMB), should be inspected (Hair et al., 2017). Therefore, those primary data issues are examined using SPSS. The issue of missing data was inspected and found that some indicators have missing percent less than 5\%, so according to the literature, we impute missing data (Hair et al., 2017) using the EM algorithm method since it provides the most accurate estimates at all levels of missing data (Little and Rubin, 2019). No outliers were detected in our dataset. CMB can be detected through running Harman's single-factor test, which is commonly used by researchers, the percentage of the factor's explained variance determines whether the bias is present or not. If the total variance of the factor is less than $50 \%$, then the common method bias does not affect the data. It was indicated that the first factor explained $34.79 \%$ of the total variance. As the value was below $50 \%$, it can be concluded that the issue of CMB had not been detected. In addition, the values of VIF were less than 3.3 confirming the absence of this problem (Kock, 2015).

\subsection{Measurement model Assessment:}

The assessment of the reflective measurement model was shown in this section. It requires evaluating the internal consistency, along with reliability, discriminant validity and convergent validity. Table (2) shows the results of both internal reliability and convergent validity through item loadings, composite reliability (CR), and average variance extracted (AVE). 
Dr. Sherif Taher Mohammed \& Dr. Sara Abd-El Fattah

Table (3): Results of reliability and validity analysis

\begin{tabular}{|c|c|c|c|c|c|c|}
\hline \multicolumn{2}{|c|}{ Variable } & Item & Loading & $\begin{array}{c}\text { Cronbach's } \\
\text { Alpha }\end{array}$ & CR & AVE \\
\hline \multicolumn{3}{|c|}{ Cutoff } & $>0.4$ & $>0.6$ & $>0.7$ & $>0.5$ \\
\hline \multirow{4}{*}{\multicolumn{2}{|c|}{$\begin{array}{l}\text { Negative Word of Mouse } \\
\text { (NWOM) }\end{array}$}} & NWOM1 & 0.815 & \multirow{4}{*}{0.721} & \multirow{4}{*}{0.829} & \multirow{4}{*}{0.55} \\
\hline & & NWOM2 & 0.825 & & & \\
\hline & & NWOM3 & 0.655 & & & \\
\hline & & NWOM4 & 0.654 & & & \\
\hline \multirow{2}{*}{\multicolumn{2}{|c|}{ Rumors }} & RUM1 & 0.783 & \multirow{2}{*}{0.639} & \multirow{2}{*}{0.841} & \multirow{2}{*}{0.727} \\
\hline & & RUM2 & 0.917 & & & \\
\hline \multirow{9}{*}{\multicolumn{2}{|c|}{$\begin{array}{c}\text { Brand Trust } \\
\text { (BT) }\end{array}$}} & BT1 & 0.844 & \multirow{9}{*}{0.904} & \multirow{9}{*}{0.924} & \multirow{9}{*}{0.581} \\
\hline & & BT2 & 0.834 & & & \\
\hline & & BT3 & 0.841 & & & \\
\hline & & BT4 & 0.854 & & & \\
\hline & & BT5 & 0.763 & & & \\
\hline & & BT6 & 0.618 & & & \\
\hline & & BT7 & 0.784 & & & \\
\hline & & BT8 & 0.772 & & & \\
\hline & & BT9 & 0.459 & & & \\
\hline \multirow{9}{*}{$\begin{array}{c}\text { Customer-brand } \\
\text { rel. } \\
\text { (CBR) }\end{array}$} & \multirow{3}{*}{ Commitment } & COM1 & 0.827 & \multirow{3}{*}{0.775} & \multirow{3}{*}{0.87} & \multirow{3}{*}{0.69} \\
\hline & & $\mathrm{COM} 2$ & 0.843 & & & \\
\hline & & COM3 & 0.822 & & & \\
\hline & \multirow{3}{*}{ Intimacy } & INTM1 & 0.725 & \multirow{3}{*}{0.69} & \multirow{3}{*}{0.829} & \multirow{3}{*}{0.618} \\
\hline & & INTM2 & 0.781 & & & \\
\hline & & INTM3 & 0.849 & & & \\
\hline & \multirow{3}{*}{ Interdependence } & INTD1 & 0.782 & \multirow{3}{*}{0.671} & \multirow{3}{*}{0.819} & \multirow{3}{*}{0.601} \\
\hline & & INTD2 & 0.749 & & & \\
\hline & & INTD3 & 0.795 & & & \\
\hline
\end{tabular}


Scientific Journal for Financial and Commercial Studies and Researches (SJFCSR) Faculty of Commerce - Damietta University

Cronbach's alpha provides the average correlation between all of the indicators that belong to one construct. The accepted value of Cronbach's alpha is 0.7 ; however, values above 0.6 are also accepted (Griethuijsen et al., 2015; Taber, 2018). All values of Cronbach's alpha in table (3) were above 0.6. Composite reliability measures the internal consistency while considering that each indicator has a different outer loading (on the contrary of Cronbach's alpha). All values of CR were above the threshold of 0.7 (Hair et al., 2017). The convergent validity of reflective measurement models is established and no items were deleted since the values of outer loadings were above 0.4 and the values of AVE were above 0.5 (Hair et al., 2017).

Table (4): Fornell-Larcker criterion

\begin{tabular}{|l|c|c|c|c|c|c|}
\hline & BT & Commitment & Interdependence & Intimacy & NWOM & Rumors \\
\hline BT & $\mathbf{0 . 7 6 2}$ & & & & & \\
\hline Commitment & 0.435 & $\mathbf{0 . 8 3}$ & & & & \\
\hline Interdependence & 0.625 & 0.612 & $\mathbf{0 . 7 7 5}$ & & & \\
\hline Intimacy & 0.455 & 0.635 & 0.621 & $\mathbf{0 . 7 8 6}$ & & \\
\hline NWOM & -0.382 & -0.556 & -0.477 & -0.493 & $\mathbf{0 . 7 4 2}$ & \\
\hline Rumors & -0.14 & 0.131 & 0.061 & 0.114 & -0.265 & $\mathbf{0 . 8 5 3}$ \\
\hline
\end{tabular}

Table (5): HTMT ratio

\begin{tabular}{|l|c|c|c|c|c|}
\hline & BT & Commitment & Interdependence & Intimacy & NWOM \\
\hline Commitment & 0.517 & & & & \\
\hline Interdependence & 0.795 & 0.837 & & & \\
\hline Intimacy & 0.565 & 0.86 & 0.883 & & \\
\hline NWOM & 0.472 & 0.743 & 0.683 & 0.692 & \\
\hline Rumors & 0.196 & 0.194 & 0.132 & 0.191 & 0.418 \\
\hline
\end{tabular}

After establishing the convergent validity, it is time to examine the discriminant validity. Discriminant validity examines how much a construct differs from other constructs. Discriminant validity is usually established by examining the Fornell-Larcker criterion or using the heterotrait-monotrait ratio (HTMT) of the correlations. Table (4) shows the results of Fornell-Larcker criterion, the square root of each 


\section{Dr. Sherif Taher Mohammed \& Dr. Sara Abd-El Fattah}

construct's AVE was reported on the main diagonal of the table, whereas the rest of the values are the inter-correlations between the construct. The idea behind this test is that the square root of each construct's AVE should be greater than its highest correlation with any other construct.

The HTMT approach is "the ratio of the between-trait correlations to the within-traits correlations". The results of HTMT values were reported in table (5), it should be lower than 0.90 (Henseler et al., 2015). Following the previous guides of the Fornell-Larcker criterion and HTMT values, the discriminant validity is constructed.

\subsection{Descriptive Statistics and Multiple Correlations}

Table (6) shows the descriptive statistics and correlations between the main variables. It can be shown that $N W O M$ has mean $(M)$, standard deviation $(S D)$, and coefficient of variation $(C V)$ as $(M=2.311, S D=0.857, C V=37.10 \%)$ with a significant negative medium correlation with customer brand since $(r(340)=-.593, P<0.001)$. Rumors construct has a descriptive statistic as $(M=3.167, S D=1.062, C V=33.55 \%)$ with a week relationship with customer-brand relationship since $(r(340)=.133, P<0.05)$. Brand trust has greatest mean and lowest variability as $(M=4.010, S D=0.672, C V=16.75 \%) \quad$ with a significant medium correlation with customer-brand relationship since $(r(340)=.559, P<0.001)$. Finally, the descriptive statistics for customer-brand relationship is ( $M=3.442, S D=0.790, C V=22.95 \%)$.

Table (6): Descriptive statistics and multiple correlations

\begin{tabular}{|l|c|c|c|c|}
\hline & NWOM & Rumors & Brand Trust & Customer Brand \\
\hline \multicolumn{1}{|c|}{ NWOM } & 1 & $-.270^{* * *}$ & $-.370^{* * *}$ & $-.593^{* * *}$ \\
\hline Rumors & & 1 & $-.148^{* *}$ & $.133^{*}$ \\
\hline Brand Trust & & & 1 & $.559^{* * *}$ \\
\hline Customer-brand rel. & & & & 1 \\
\hline Mean & 2.311 & 3.167 & 4.010 & 3.442 \\
\hline Std. Deviation & 0.857 & 1.062 & 0.672 & 0.790 \\
\hline CV & $37.10 \%$ & $33.55 \%$ & $16.75 \%$ & $22.95 \%$ \\
\hline Skewness & 0.463 & 0.038 & -1.031 & -0.176 \\
\hline Kurtosis & -0.039 & -0.788 & 1.722 & -0.156 \\
\hline
\end{tabular}

${ }^{*} \mathrm{P}<0.05,{ }^{* *} \mathrm{P}<0.01,{ }^{* * *} \mathrm{P}<0.001$ 
Scientific Journal for Financial and Commercial Studies and Researches (SJFCSR) Faculty of Commerce - Damietta University

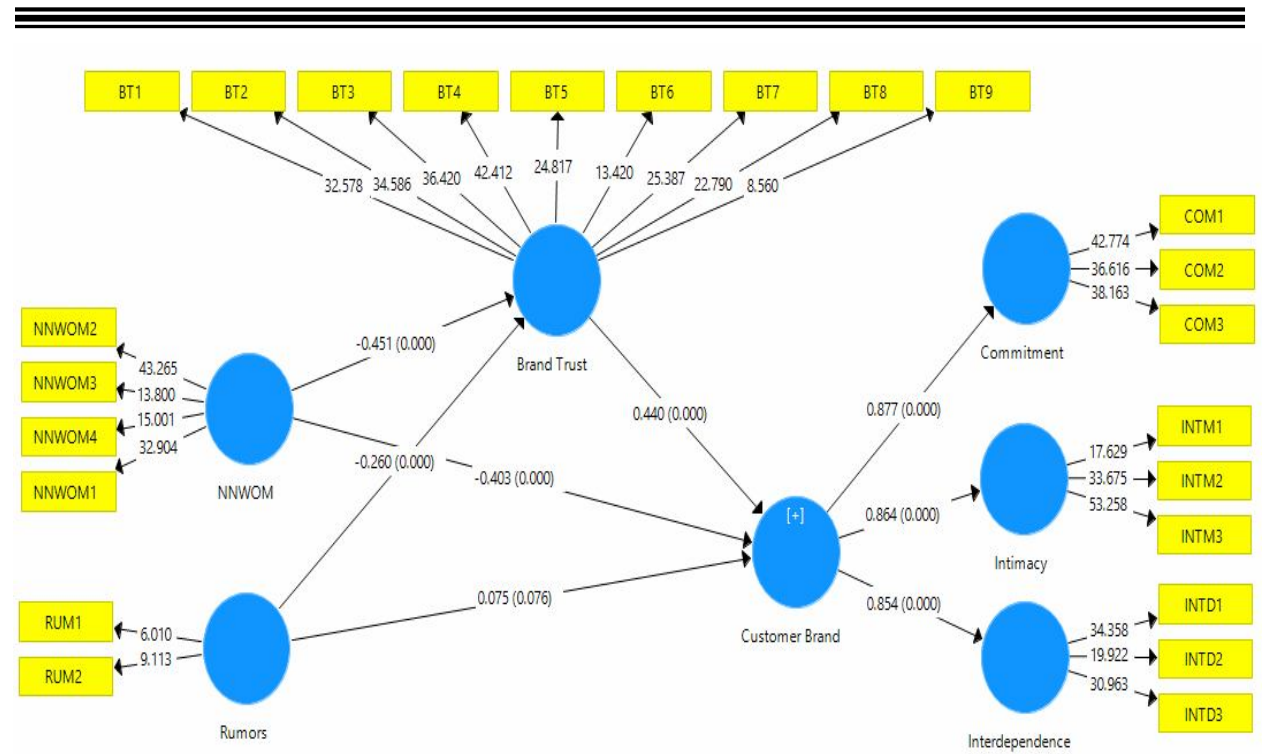

Figure (2): Structural model for testing the main hypothesis

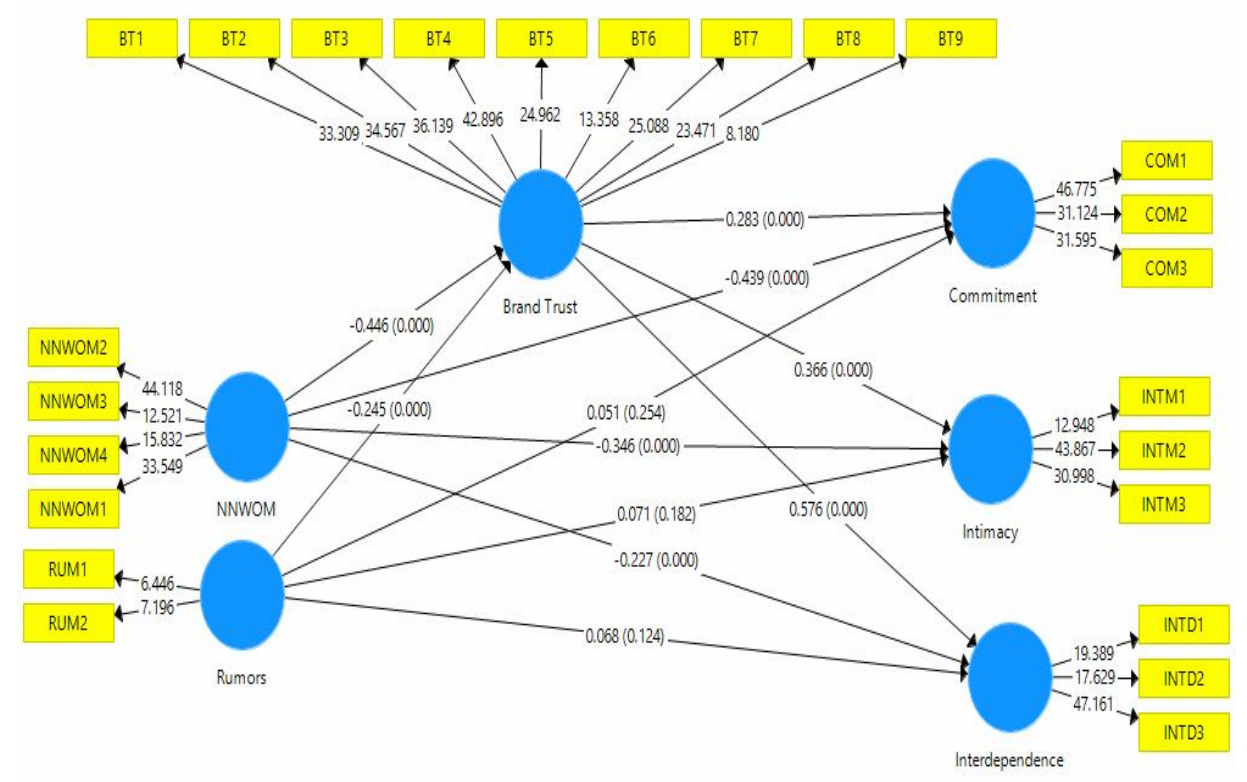

Figure (3): Structural model for testing the sub-hypothesis 


\section{Dr. Sherif Taher Mohammed \& Dr. Sara Abd-EI Fattah}

\subsection{Structural model Assessment}

Examining the structural model includes path coefficients, collinearity diagnostics, coefficient of determination $\left(\mathrm{R}^{2}\right)$, effect size $\left(\mathrm{f}^{2}\right)$, predictive relevance $\left(\mathrm{Q}^{2}\right)$, and goodness of fit criteria.

Table (7): Hypothesis testing

\begin{tabular}{|c|c|c|c|c|c|c|}
\hline \multirow{2}{*}{ Path } & \multirow{2}{*}{$\boldsymbol{\beta}$} & \multirow{2}{*}{ t-value } & \multirow{2}{*}{ P-value } & \multicolumn{2}{|c|}{$95 \%$ CI } & \multirow{2}{*}{ Remark } \\
\hline & & & & LL & UL & \\
\hline \multicolumn{7}{|c|}{ Direct Effect } \\
\hline H1: NWOM -> Customer-brand rel. & -0.403 & 8.797 & $.000^{* * *}$ & -0.497 & -0.316 & Accepted \\
\hline H1a: NWOM -> Commitment & -0.439 & 9.417 & $.000^{* * *}$ & -0.531 & -0.346 & Accepted \\
\hline H1b: NWOM -> Intimacy & -0.346 & 6.12 & $.000^{* * *}$ & -0.458 & -0.236 & Accepted \\
\hline H1c: $N W O M$-> Interdependence & -0.227 & 4.921 & $.000^{* * *}$ & -0.312 & -0.133 & Accepted \\
\hline H2: Rumors -> Customer-brand rel. & 0.075 & 1.774 & $.076^{\mathrm{NS}}$ & -0.01 & 0.153 & Rejected \\
\hline H2a: Rumors -> Commitment & 0.051 & 1.141 & $.254^{\mathrm{NS}}$ & -0.031 & 0.142 & Rejected \\
\hline H2b: Rumors $->$ Intimacy & 0.071 & 1.335 & $.182^{\mathrm{NS}}$ & -0.031 & 0.179 & Rejected \\
\hline H2c: Rumors -> Interdependence & 0.068 & 1.538 & $.124^{\mathrm{NS}}$ & -0.015 & 0.157 & Rejected \\
\hline H3: NWOM -> Brand Trust & -0.451 & 7.92 & $.000^{* * *}$ & -0.563 & -0.334 & Accepted \\
\hline H4: Rumours -> Brand Trust & -0.26 & 4.158 & $.000^{* * * *}$ & -0.364 & -0.13 & Accepted \\
\hline H5: Brand Trust -> Customer-brand rel. & 0.44 & 9.964 & $.000^{* * *}$ & 0.35 & 0.523 & Accepted \\
\hline H5a: Brand Trust $->$ Commitment & 0.283 & 5.515 & $.000^{* * *}$ & 0.176 & 0.378 & Accepted \\
\hline H5b: Brand Trust $->$ Intimacy & 0.366 & 6.007 & $.000^{* * *}$ & 0.246 & 0.481 & Accepted \\
\hline H5c: Brand Trust $->$ Interdependence & 0.576 & 13.458 & $.000^{* * *}$ & 0.495 & 0.662 & Accepted \\
\hline \multicolumn{7}{|c|}{ Indirect Effect } \\
\hline H6: NWOM -> Brand Trust -> Customer-brand rel. & -0.199 & 7.018 & $.000^{* * * *}$ & -0.258 & -0.145 & Accepted \\
\hline H6a: NWOM -> Brand Trust $->$ Commitment & -0.126 & 4.814 & $.000^{* * * *}$ & -0.179 & -0.077 & Accepted \\
\hline H6b: NWOM -> Brand Trust $->$ Intimacy & -0.163 & 5.047 & $.000^{* * *}$ & -0.229 & -0.104 & Accepted \\
\hline H6c: NWOM -> Brand Trust $->$ Interdependence & -0.257 & 7.03 & $.000^{* * *}$ & -0.329 & -0.19 & Accepted \\
\hline H7: Rumors -> Brand Trust -> Customer-brand rel. & -0.115 & 3.59 & $.000^{* * *}$ & -0.174 & -0.047 & Accepted \\
\hline H7a: Rumors -> Brand Trust $->$ Commitment & -0.069 & 2.984 & $.003^{* *}$ & -0.116 & -0.027 & Accepted \\
\hline H7b: Rumors $->$ Brand Trust $->$ Intimacy & -0.09 & 2.938 & $.003^{* *}$ & -0.152 & -0.033 & Accepted \\
\hline H7c: Rumors -> Brand Trust $->$ Interdependence & -0.141 & 3.488 & $.000^{* * * *}$ & -0.217 & -0.06 & Accepted \\
\hline
\end{tabular}

${ }^{*} \mathrm{P}<0.05,{ }^{* *} \mathrm{P}<0.01,{ }^{* * *} \mathrm{P}<0.001,{ }^{\text {NS }}$ Not Significant. 
Scientific Journal for Financial and Commercial Studies and Researches (SJFCSR) Faculty of Commerce - Damietta University

Figure (2) shows the estimated model with the estimated path coefficients of the main hypotheses along with the corresponding $\mathrm{p}$ values, while that of the sub-hypothesis were shown in figure (3). The results of the first main hypothesis show that; NWOM has statistically significant negative effect on customer-brand relationship since $(\beta=-0.403, t=8.797, P<0.001,95 \% C I$ for $\beta=[-0.497,-0.316])$ . NNWOM also has negative effect on the dimensions of customer-brand relationship as [commitment $(\beta=-0.439)$ intimacy $(\beta=-0.346)$ and interdependence $(\beta=-0.227)]$ with $P<0.001$. On the hand, rumors has no effect on customer brand since $(\beta=0.075, t=1.774, P>0.05,95 \% C l$ for $\beta=[-0.01,0.153])$.

Rumors also has no effect on the dimensions of customer-brand relationship as $[$ commitment $(\beta=0.051)$ intimacy $(\beta=0.071)$ and interdependence $(\beta=0.068)]$ with $P>0.05$.

The third hypothesis showed that $N W O M$ has significant negative effect on brand trust since $(\beta=-0.451, t=7,92, P<0.001,95 \%$ C $]$ for $\beta=[-0.563,-0.334])$. Moreover, rumors construct has significant negative effect on brand trust since

$(\beta=-0.26, t=4.158, P<0.001,95 \% C I$ for $\beta=[-0.364,-0.13])$, so, the fourth hypothesis is accepted. However, brand trust has significant poisitive effect on customer-brand relationship since $(\beta=0.44, t=9.964, P<0.001,95 \% C I$ for $\beta=[0.35,0.523])$. Brand trust also has positivee effect on the dimensions of customer-brand relationship as [commitment $(\beta=0.283)$ intimacy $(\beta=0.366)$ and interdependence $(\beta=0.576)]$ with $P<0.001$.

The mediation analysis yielded a significant negative indirect relationship between $N W O M$ and customer-brand relationship through brand trust since $\left(\beta_{\text {Indirect }}=-0.199, t=7.018, P<0.001,95 \% \mathrm{CI}\right.$ for $\beta_{\text {Indirect }}=$ $[-0.258,-0.145])$

Brand Trust also mediates the relationship between NWOM and the dimensions of customer-brand relationship as $\left[\right.$ commitment $\left(\beta_{\text {Indirect }}=-0.126\right) \quad$ intimacy $\left(\beta_{\text {Indirect }}=-0.163\right)$ and interdependence $\left.\left(\beta_{\text {Indirect }}=-0.257\right)\right]$ with $P<0.001$. Since, the direct 


\section{Dr. Sherif Taher Mohammed \& Dr. Sara Abd-El Fattah}

and indirect reltionships are both significant, so we can conculde that brand trust partially mediates the relationship between NWOM and customer brand.

The mediation analysis also provided a weak negative indirect relationship between rumors and customer-brand relationship through brand trust since $\left(\beta_{\text {Indirect }}=-0.115, t=3.59, P<0.001,95 \% \mathrm{Cl}\right.$ for $\left.\beta_{\text {Indirect }}=[-0.174,-0.047]\right)$. Brand Trust also mediates the relationship between rumors and the dimensions of customer-brand relationship as [commitment $\left(\beta_{\text {Indirect }}=-0.069, \mathrm{P}<0.01\right) \quad$ intimacy $\left(\beta_{\text {Indirect }}=-0.09, \mathrm{P}<0.01\right)$ and interdependence $\left.\left(\beta_{\text {Indirect }}=-0.141, \mathrm{P}<0,001\right)\right]$.

Table (8): Evaluating the model with the main hypotheses

\begin{tabular}{|l|c|c|c|c|}
\hline & \multicolumn{2}{|c|}{ Brand Trust } & \multicolumn{2}{c|}{ Customer-Brand rel. } \\
\hline & Effect Size & VIF & Effect Size & VIF \\
\hline Brand Trust & & & 0.309 & 1.263 \\
\hline NWOM & 0.239 & 1.076 & 0.245 & 1.332 \\
\hline \multicolumn{1}{|c|}{ Rumors } & 0.079 & 1.076 & 0.01 & 1.161 \\
\hline$R$ Square & \multicolumn{2}{|c|}{0.208} & \multicolumn{2}{c|}{0.504} \\
\hline$R$ Square Adjusted & 0.204 & \multicolumn{2}{c|}{0.499} \\
\hline Q Square & \multicolumn{2}{|c|}{0.117} & \multicolumn{3}{|c|}{} \\
\hline GoF & \multicolumn{3}{|c|}{0.473} \\
\hline
\end{tabular}

The Results in table (8) indicate that about $21 \%$ of the variation in brand trust is explained by the variation in both NWOM and rumors with Cohen's effect size $\left(f^{2}=0.239,0.079\right)$ indicating moderate and small effect respectively. In addition, there are $50 \%$ of the variation in customer-brand relationship is explained by the variation in all other variables with Cohen's effect size $\left(f^{2}=0.309\right.$ for Brand Trust $),\left(f^{2}=\right.$ 0.245 for $N W O M)$, and $\left(f^{2}=0.01\right.$ for Rumors $)$, indicating medium effect for brand trust and NWOM, and no effect for rumors. All values of variance inflation factor (VIF) were below 5 indicating the absence of collinearity problem. We evaluated predictive relevance by assessing Stone-Geisser's $Q^{2}$ Blindfolding is a sample reuse technique that can be 
Scientific Journal for Financial and Commercial Studies and Researches (SJFCSR) Faculty of Commerce - Damietta University

used to calculate $Q^{2}$ values for latent variables. We executed the blindfolding procedure and calculated the $Q^{2}$ values for brand trust $\left(Q^{2}\right.$ $=0.117)$, and customer-brand relationship $\left(Q^{2}=0.233\right)$. All values were greater than zero, thus indicate predictive relevance for endogenous latent variables in our PLS path model (Hair et al. 2017).

Table (9): Evaluating the model with the sub-hypotheses

\begin{tabular}{|c|c|c|c|c|c|c|}
\hline & \multicolumn{2}{|c|}{ Commitment } & \multicolumn{2}{c|}{ Interdependence } & \multicolumn{2}{c|}{ Intimacy } \\
\hline & Effect Size & VIF & Effect Size & VIF & Effect Size & VIF \\
\hline Brand Trust & 0.103 & 1.246 & 0.518 & 1.246 & 0.168 & 1.246 \\
\hline NWOM & 0.233 & 1.332 & 0.075 & 1.332 & 0.141 & 1.332 \\
\hline Rumors & 0.004 & 1.159 & 0.008 & 1.159 & 0.007 & 1.159 \\
\hline $\boldsymbol{R}$ Square & 0.378 & 0.486 & 0.361 \\
\hline $\boldsymbol{R}$ Square Adjusted & 0.373 & 0.481 & 0.356 \\
\hline $\boldsymbol{Q}$ Square & 0.249 & \multicolumn{7}{|c|}{0.276} & \multicolumn{2}{c|}{0.202} \\
\hline GoF & \multicolumn{7}{|c|}{0.473} \\
\hline
\end{tabular}

The Results in table (9) indicate that about $38 \%$ of the variation in commitment is explained by the variation in brand trust, NWOM, and rumors with Cohen's effect size $\left(f^{2}=0.103\right.$ for Brand Trust $),\left(f^{2}=0.233\right.$ for $N W O M)$, and $\left(f^{2}=0.004\right.$ for Rumors $)$, indicating small, medium, and no effect respectively. In addition, there are $49 \%$ of the variation in interdependence is explained by the variation in brand trust, NWOM, and rumors with Cohen's effect size $\left(f^{2}=0.518\right.$ for Brand Trust $),\left(f^{2}=0.075\right.$ for $N W O M$ ), and ( $f^{2}=0.008$ for Rumors), indicating strong, small, and no effect respectively. Finally, there are $36 \%$ of the variation in intimacy is explained by the variation in brand trust, NWOM, and rumors with Cohen's effect size $\left(f^{2}=0.168\right.$ for Brand Trust $),\left(f^{2}=0.141\right.$ for NWOM), and $\left(f^{2}=0.007\right.$ for Rumors $)$, indicating medium, small, and no effect respectively. All values of variance inflation factor (VIF) were below 5 indicating the absence of collinearity problem. The $Q^{2}$ values for commitment $\left(Q^{2}=0.249\right)$, for interdependence $\left(Q^{2}=0.276\right)$, and intimacy $\left(Q^{2}=0.202\right)$. All values were greater than zero, thus indicate predictive relevance for endogenous latent variables in our PLS path model. Tenenhaus et al. (2005), proposed the Goodness of Fit (GoF) as a global 


\section{Dr. Sherif Taher Mohammed \& Dr. Sara Abd-El Fattah}

fit indicator. The criteria of GoF for deciding whether GoF values are not acceptable, small, moderate, or high to be regarded as a globally appropriate PLS model. The value of the GOF $(0.473)$ is greater than 0.36 indicating high fit, so, it can be safely concluded that the GoF model is large enough to considered sufficient valid global PLS model.

\section{5- Conclusion and Discussion:}

This study builds up a research model to explore the impact of rumours and NWOM on customer-brand relationship and to discuss the mediating effect of brand trust. In other words, this study provides strategies to handle rumours and NWOM as a way to enhance brand relationship via the mediating role of brand trust. This research has three main contributions. First, it takes in part in closing the literature gap related to the relationship between NWOM, rumours and customer-brand relationship in the Egytian laboratories. Second, the study confirmed that the Egyptian customers are more concerned with NWOM rather than rumours. Finally, the study instructs Egytian managers to take brand trust as well as customer-brand relationship into their considerations as main priorities that can elevate brand loyalty.

Firstly, NWOM was detected to have a direct and indirect negative significant effect on customer-brand relationship (H1,H6 and H6a,b,c were accepted) and also NWOM has negative significant effect on customer-brand relationship dimensions (Commitment, Intimacy and Interdependence) respectively (H1a,b,c were accepted) as it was accepted with (Sundaram and Webster, 1999) as they have emphasized on avoiding any NWOM communication because it has an enormous negative influence on brand name, brand evaluation, and on consumer behavior toward dealing and purchasing services or goods from this brand name. Also, factors like heterogeneity and integrity can be the primary factors of brand trust that affects the consumers behavior when purchasing this brand name. In addition, researchers (Martin and Lueg, 2103 and Guo, 2015) have reached that whether the NWOM is done offline or online, they have the same effect on the brand name as in; decrease in brand trust, decrease in purchase intentions, decrease in brand relationship, decrease in consumers commitment toward the brand name. All these outcomes fall under behavioral and non-behavioral outcomes. However, rumours negatively affected customer-brand relationship and 
Scientific Journal for Financial and Commercial Studies and Researches (SJFCSR) Faculty of Commerce - Damietta University

it's dimensions (Commitment, Intimacy and Interdependence) through the mediating effect of brand trust ( $\mathrm{H} 7$ and $\mathrm{H} 7 \mathrm{a}, \mathrm{b}, \mathrm{c}$ were accepted) but there is no direct relationship between ( $\mathrm{H} 2$ and $\mathrm{H} 2 \mathrm{a}, \mathrm{b}, \mathrm{c}$ were rejected) this is differ from the studies by (Borodina \& Zheltukhina, 2013; 2015a; 2015b; Bordia et al. 2006) which found that rumours has a negative impact on brands.

In this research, multiple regression analysis results recommend that the brand trust has a statistically relevent influence on customerbrand relationship and it's dimensions (Commitment, Intimacy and Interdependence), holding other factors constant (H5 \& H5a,b,c were accepted). While brand trust was found by the current study researchers as well these researchers (Kim, Park \& Kim, 2013; Lee \& Kang, 2013; Volta, 2013 and Kang, Tang \& Fiore, 2014) that it has an influence in creating brand relationship with consumers so laboratories managers should distribute their resources better and increase their efforts to boost a long lasting consumer brand relationship (Johnson \& Selnes, 2004). Researchers have attempted to locate the sources of consumer-brand relationship that will enhance the concept during this time. Traditional antecedents of consumer-brand relationship included brand personality (Lee \& Kang, 2013; Volta, 2013), brand identity (Albert \& Merunka, 2013; Lee \& Kang, 2013), brand reliability (Hess, Story \& Danes, 2011), brand fidelity (Hess, Story \& Danes, 2011), social media interaction (Hudson et al., 2015), brand trust (Albert \& Merunka, 2013;), brand uniqueness (Volta, 2013), relationship norms (Volta, 2013), brand attachment (Lourerio, Ruediger \& Demetris, 2012), and brand selfexpression (Lourerio, Ruediger \& Demetris, 2012). Better repercussions for consumer brand relationship can be produced through these constructs. Besides, NWOM and rumours have a statistically significant effect on brand trust (H3 \& H4 were accepted) which is consistent with (Portal, Abratt, Bendixen, 2019) study that found that brands are becoming the spotlight of unethical behaviors which results in decreasing the brand trust and in return can affect the commitment in the relationship between the customer and the brand. In addition, researchers (Pantano and Corvello, 2013) found that NWOM can be handled to improve business profit and reputations through solving the opinions and the problems of consumers as social media prefer to leave the negative 


\section{Dr. Sherif Taher Mohammed \& Dr. Sara Abd-El Fattah}

comments on brand names for the knowledge that these comments have the ability to attract more consumers to the page or website. While researchers (Moreira, Silva and Mouhinho, 2017) have found that brand experiences and satisfaction are important factors in brand trust which results in affecting the consumer-brand relationship and they have found that rapid innovation technology has a negative influence on consumers' satisfaction toward the brand name as these new technologies has helped in the spreading of negative comments faster.

\section{6- Limitations and future researches:}

The current study investigated a complicated phenomenon in an area that is considered under-researched. Although the current study has undeniable limitations, the findings demonstrate a variety of upcoming research guidelines. Initially, we did not investigate the demography characteristics and the behavioural characteristics (gender, age, amount of time spent on social platforms, brand engagement etc.). Further studies could focus on other healthcare services such as radiology, imaging and development as well as using larger respondents (such as surveying people from other countries). Additionally, we could perceive that there are attainable guidelines for any upcoming research as studying the impact of brand hatred, brand experience and identity avoidance and customer-brand relationship. This would assist in establishing if the negative motive can have the effect on the individuals who trust and love the brand as on the individuals who are indifferent towards it. Additionally, the current research investigates the brand relationship depends on (commitment, intimacy and interdependence) and brand trust depends on (brand credibility, integrity and benevolence), future studies can use other sub-variables such as (love and passion, self-connection, satisfaction, relationship duration).

Studies that are going to be done in the future can proceed our conclusions and findings by inspecting further the relationships of possible characteristics of consumers, social network position, and new service's features, etc. Depending on these effects the consumer invests his/her time and effort. Furthermore, future studies may explore the variable and fixed costs of each customer associating the offering of the service presented to them. Finally, researchers can estimate how policies for handling NWOM and rumours may affect these separate groups, and 
Scientific Journal for Financial and Commercial Studies and Researches

(SJFCSR) Faculty of Commerce - Damietta University

the consequences effect on customer-brand relationship. As for coming extension of this work in the future, the researchers tend to offer a broaden model with more states to contemplate rumour control parameters and variables such as image and reputation.

Ultimately, future researches may focus on enlarging the content of consumer-brand relationships as the literature review explored that there are numerous types of consumer-brand relationships varying across different levels of brand relationship strength (Avery, Fournier \& Wittenbraker 2014). For example, alliance of brand relationships is identified by high level of trust and quality, as compared to casual brand relationships that is identified by low level intimacy (Fournier 1998 and Avery, Fournier \& Wittenbraker 2014). Upcoming researches may require to appraise segmenting the consumers, based on kinds of relationship, and examining the effects of relationship standards that lead to the interlinkage between consumers and brands for each kind (Avery, Fournier \& Wittenbraker 2014; Oliver 1999; Sreejesh \& Mohapatra 2014; Rossiter, Percy \& Donovan 1991)

\section{7- Managerial implications:}

The current research attempted to respond to the question: Can negative word-of-mouth and rumours have a negative effect on customerbrand relationship (i.e., deciding that they won't purchase the brand again)? The respond to this question is essential because any laboratory is sensitive to any risk concerning NWOM (either honest or fake) and rumours, leading to unpleasant consequences for its name and reputation. The acquired results illustrated that negative actions can probably affect consumer behaviour, triggering an instrument of rejecting the brand that ultimately can be translated into brand image collapse (due to NWOM) and declining of sales. The managers of brand communication should be aware of this instrument and discover constructive ways to prevent it. An official response issued by the company is essential, whenever a problem arises. For this to be practical, the Egyptian laboratories should purposefully keep track on its online appearance, so as to find out what the customers are spreading and whether it is positive or negative and where they are spreading it. Moreover, the behaviours based on the customers' acceptance of critiques are common among firms with experience when compared to firms with less experience which ignore 


\section{Dr. Sherif Taher Mohammed \& Dr. Sara Abd-El Fattah}

the complaints of their consumers'. Laboratories learn from incidents that paying attention to consumers' complaints, helps in avoiding the spread of NWOM. For this cause, in preference to extracting negative comments or asking customers to remove them, managers could bid their customers to add their observations. Managers should pursue in charging activities that enhance the relationship of the brand with consumers online and utilize the PWOM advantages to strengthen their image. New web-based strategies of brand-customer relationship management should be raised to achieve the goal of replying to the on-going development of technology.

There are a hardly any strategies that can diminish the harmful effect of the NWOM. Firstly, a swift response to negative appraisals is always essential as this swift response will revel to customers that the laboratory cares and values their opinion leading to reducing the hate and the opposition from the customers' part. In addition, it is preferable that the laboratory attend to annoyed consumers offline to resolve their problems. Contacting the customer directly provides better chance to settle the problem to the satisfy the customer. Eventually, laboratory representatives can present a published message to let the people aware about the method used to handle the problem.

Through these methods the company's name and reputation could be restored, assuring the customers to give the laboratory a second chance. Additionally, increase awareness among marketers that the subject of rumours can be a hazard to laboratories, and what causes marketing dilemma, and methods of dealing with rumours and the ways of investigation and giving feedback; through training sessions in managing the marketing crises in general and rumours precisely, or by motivating consumers to access the references. Researches in this field also can establish a specialized unit to contact customers and try to use effective marketing strategies to prevent rumours through using several methods that could involve marketing intelligence, marketing research, measuring the attitude and satisfaction of customers. According to these recommendations, managers can create more chances for consumers to have a constructive experience and closer ties with their brands. Once the consumers' emotions with the brand is powerful and they have the chance to acknowledge that the brand is trustworthy and of high quality, they will figure out that the NWOM they are exposed to and the rumours 
Scientific Journal for Financial and Commercial Studies and Researches (SJFCSR) Faculty of Commerce - Damietta University

are fake which will result in their future judgement in dealing with the brand.

Simultaneously, the laboratory representatives should not abandon to ask the review websites to eliminate scandalous and vicious reviews, only written to hurt the brand name. If non-based and false comments are removed within an instant, their unfavourable impact will be limited on customer behaviour. Nevertheless, when the commentators are genuine, then it is the laboratory's liability; acknowledging the downside and facing the results to retain the consumers' trust, averting an outbreak of loathing toward the brand and steering clear of probable negative influence regarding selling and profit cutback.

The current study results have suggestions for composing more productive loyalty programs as customers who are loyal are less probable to be affected by NWOM. Additionally, individuals are more presumably to talk positively about a brand name they like or possess and spread NWOM about a brand name they detest or do not possess. They are also more apparently to be influenced by PWOM about a brand they like and by NWOM about a brand they dislike. Thus, laboratories need to go through more assets on their customer loyalty programs and on their support services. Additionally, laboratories need to observe those who do not utilize their brand name. In particular, $78 \%$ of PWOM is being generated by current users, while $49 \%$ non-users of a brand and $30 \%$ who have never used it have the ability to initiate NWOM about the brand name (East, Hammond, and Wright, 2007). Furthermore, individuals who do not utilize the products or the service of the brand name are likely to spread NWOM as well (Wangenheim, 2005). Eventually, the government must make a rumour-fighting unit especially during the pandemic which follows the administration of State Information Service, which can be entered through its website to probe about the rumours being accurate or not, and abolishing the fake information before it spreads further and enhance extra laws to resist electronic violations in different categories and forms, given the constrains of the existing regulation, which should include distribution of rumours as a crime that need to be addressed. Further, researchers explored the consumer-brand relationships effect on the development of the quality bonds between consumers and their brands (Nober, 2011). Researchers noticed positive end-result of 


\section{Dr. Sherif Taher Mohammed \& Dr. Sara Abd-El Fattah}

powerful consumer brand relationship (Cheng, White \& Chaplin, 2012) e, g. brand commitment (Albert \& Merunka, 2013), brand forgiveness (Cheng, White \& Chaplin, 2012), positive word of mouth (Albert \& Merunka, 2013; Fetscherin et al., 2014; Hudson et al., 2015), brand loyalty (Fetscherin et al., 2014; Lourerio, Ruediger \& Demetris, 2012; Volta, 2013), purchase intention (Lee \& Kang, 2013; Fetscherin et al., 2014), brand evaluation (Kim, Park \& Kim, 2013) and brand extension (Kim, Park \& Kim, 2013). All these consequences produce better value for the brands.

\section{8- Theoretical implications:}

Theoretical implication is a newly found edition to existing theories or as a building for new theories. The almost total lack of researchs evidence on the switching of negative impact of NWOM and rumors on service, urged us as researches to address this evidence by using marketing tactics on the customer-brand relationship and brand trust. Our survey was done by directly observing the customers of the Egyptian laboratories. The theoretical implications that NWOM and rumors shape customer-brand relation should not be ignored by researchers seeking to define the strong brand trust characteristics. Finally, there are tremendously important empirical and theoretical implications of using a research model to examine a single construct over time.

\section{References}

1. Aaker J., Fournier S. and Brasel S. A., (2001), "How to measure brand relationship quality? Charting the development of consumerbrand relationships", Research Paper Series, Graduate School of Business Stanford University.

2. Abd Ghani, N.H. B., and Tuhin, M. K. W., (2016), "Consumer Brand Relationships", International Review of Management and Marketing, Vol. 6, No.4.

3. Aggarwal, P., (2004), "The effects of brand relationship norms on consumer attitudes and behavior", The Journal of Consumer Research, Vol. 31, No. 1. 
Scientific Journal for Financial and Commercial Studies and Researches (SJFCSR) Faculty of Commerce - Damietta University

4. Ahmed, Z., (2014), "Effect of brand trust and customer satisfaction on brand loyalty in Bahawalpur", Journal of Sociological Research, Vol. 5, No. 1.

5. Albert, N. \& Merunka, D., (2013), "The role of brand love in consumer-brand relationships", Journal of Consumer Marketing, Vol. 30, No. 3.

6. Alexandrov, A., Lilly, B., \& Babakus, E., (2013), "The effects of social-and self-motives on the intentions to share positive and negative word of mouth", Journal of the Academy of Marketing Science, Vol. 41, No.5.

7. Amani Z., (2015), "Commitment as a Mediator of the Relationship between Trust and Relationship Loyalty to Retailer", Journal of Business Studies Quarterly, Vol.6, No.3.

8. Amoozgar, M., Ramezanian R., (2014), "A computational model and convergence theorem for rumor dissemination in social network", The ISC International Journal of Information Security, Vol. 5, No. 2.

9. Anderson, E. W., (1998), "Customer satisfaction and word of mouth", Journal of Service Research, Vol. 1, No. 1.

10. Anderson, J. C., \& Narus, J. A., (1990), "A model of distributor firm and manufacturer firm working partnerships", Journal of Marketing, Vol. 54, No. 1.

11. Aramendia-Muneta, M.E., (2017), "Spread the Word - The Effect of Word of Mouth in e-Marketing", conference paper, 2017.

12. Avery, J, Fournier, S \& Wittenbraker, J 2014, 'Unlock the mysteries of your customer relationships', Harvard Business Review, vol. 92, no. 7 , pp. $72-81$.

13. Azize, S., Cemal, Z. and Hakan, K., (2012), "Does Brand Communication Increase Brand Trust? The Empirical Research on Global Mobile Phone Brands", Social and Behavioural Sciences, Vol.58, No. 5.

14. Bae, S. and Lee, T., (2011a), "Gender differences in consumers' perception of online consumer reviews", In Electronic Commerce Research and Applications, Vol. 11 No.2. 


\section{Dr. Sherif Taher Mohammed \& Dr. Sara Abd-El Fattah}

15. Barcelos, R., Dantas, D., Sénécal, S., and Rossi, C., (2016), “The Effect of Brand Intimacy on Consumer Responses: An Application on a Social Media Context", Academy of Marketing Science, In book: Rediscovering the Essentiality of Marketing. Developments in Marketing Science: Proceedings of the Academy of Marketing Science (pp.209-214), Publisher: Springer

16. Beneke, J., de Sousa, S., Mbuyu, M., Wickham, B, (2015), "The effect of negative online customer reviews on brand equity and purchase intention of consumer electronics in South Africa", The International Review of Retail, Distribution and Consumer Research, Vol. 26, No. 2.

17. Berger, J., (2014), "Word of mouth and interpersonal communication: A review and directions for future research", Journal of Consumer Psychology, Vol.24, No.4.

18. Blackston, M., (2000), "Observations: building brand equity by managing the brand's relationships", Journal of Advanced Research, Vol. 40.

19. Blackston, M., and Lebar, E., (2015), "Constructing consumerbrand relationships to better market and build businesses", In: Fournier, S., Breazeale, M., Avery, J., editos. Strong Brands, Strong Relationships. Abingdon, Oxon: Routledge; p.376.

20. Bordia, P., DiFonzo, N., Haines, R. and Chaseling, E., (2005), "Rumor Denials as Persuasive Messages: Effects of Personal Relevance, Source, and Message Characteristics," Journal of Applied Social Psychology, Vol. 35, No. 6.

21. Bordia, P., Jones, E., Gallois, E.C., Callan, V. J., and DiFonzo, N., (2006), "Management are Aliens! Rumors and Stress during Organizational Change," Group \& Organization Management, Vol. 31, No. 5.

22. Borodina, S.N. \& Zheltukhina, M.R., (2013), "Rumors and their Function in the Modern Media Discourse.", Person. Language. Culture: Scientific Articles Coll. Kiev: Print. House D. Burago. 
Scientific Journal for Financial and Commercial Studies and Researches (SJFCSR) Faculty of Commerce - Damietta University

23. Borodina, S.N. \& Zheltukhina, M.R., (2015a), "Grammatical Means of Rumors' Influence in Russian and English Mass Media", Bulletin of the Moscow City Teacher Training University. Series: Philology. Theory of Language. Language Education, Vol. 18, No. 2.

24. Borodina, S.N. \& Zheltukhina, M.R., (2015b), "Strategies and Tactics of Rumour Realization in Foreign Mass Media", Proceedings of the Volgograd State Pedagogical University, Vol. 96, No. 1.

25. Bowden, J., (2009), "Customer Engagement: A Framework for Assessing Customer-Brand Relationships: The Case of the Restaurant Industry", Journal of Hospitality Marketing \&Management, Vol. 18, No. 6.

26. Bruhn, M., Eichen, F., Hadwich, K. \& Tuzovic, S., (2012), "Conceptualizing and measuring brand relationship quality", In $S$ Fournier, M Breazeale \& M Fetscherin (eds), Consumer-brand relationships: Theory and practice, Taylor \& Francis, London, pp. 165-83.

27. Cambier F, Poncin I., (2018), "Proclaiming brand transparency: An effective strategy for advertising customer-ideated new products", AFM International Congress.

28. Chan, H., \& Cui, S., (2011), "The contrasting effects of negative word of mouth in the post-consumption stage.", Journal of Consumer Psychology, Vol. 21, No. 3.

29. Chang, P.L. \& Chieng, M.H., (2006), "Building consumer-brand relationship: a cross-cultural experiential view", Psychology \& Marketing, Vol. 23, No. 11.

30. Charton-Vachet, F., and Lombart, C., (2018), "Impact of the link between individuals and their region on the customer-regional brand relationship", Journal of Retail Consumer Survey, Vol. 43.

31. Chaudhuri A., Holbrook, M.B., (2001), "The chain of effects from brand trust and brand affect to brand performance: The role of brand loyalty", Journal of Marketing, Vol.65, No.2. 


\section{Dr. Sherif Taher Mohammed \& Dr. Sara Abd-El Fattah}

32. Chen, G., (2016), "New challenges from popular politics: NGOs, commercial organizations, social media, and civic society", In The Politics of Disaster Management in China, Palgrave Macmillan US, pp. 93-108

33. Cheng, S.Y., White, T.B. \& Chaplin, L.N. ,(2012), "The effects of self-brand connections on responses to brand failure: A new look at the consumer-brand relationship", Journal of Consumer Psychology, Vol. 22, No. 2.

34. Chiosa, A. R., and Anastasiei, B., (2017), "Negative Word-of Mouth: Exploring the Impact of Adverse Messages on Consumers' Reactions on Facebook", Review of Economic and Business Studies, Vol.10, issue 2.

35. Choi, S. H., (2012), "The effects of brand trust dimensions on consumers' economic and social loyalty behavior", Consumption Culture Study, Vol. 15, No. 2.

36. Clark, M. S., and Mills, J., (2011), "A theory of communal (and exchange) relationships," in Handbook of Theories of Social Psychology: eds P. A. M. Van Lange, A. W. Kruglanski, and E. T. Higgins, (Thousand Oaks, CA: Sage), p.p.232-250.

37. Coelho, P. S., Rita, P., and Santos, Z. R., (2018), "On the relationship between consumer-brand identification, brand community, and brand loyalty", Journal of Retail Consumer Service, Vol. 43.

38. D.S. Sundaram and Cynthia Webster, (1999),"The Role of Brand Familiarity on the Impact of Word-Of-Mouth Communication on Brand Evaluations", in NA - Advances in Consumer Research Volume 26, eds. Eric J. Arnould and Linda M. Scott, Provo, UT : Association for Consumer Research, Pages: 664-670.

39. Dalziel N., Harris F., Laing A., (2011), "A multidimensional typology of customer relationships: From faltering to affective", International Journal of Bank Marketing, Vol. 29, No.5.

40. Delgado-Ballester, E., Munuera-Aleman, J. L., \& Yague-Guillen, M. J. (2003), "Development and validation of a brand trust scale", International Journal of Market Research, Vol.45, No.1. 
Scientific Journal for Financial and Commercial Studies and Researches (SJFCSR) Faculty of Commerce - Damietta University

41. DiFonzo, N., and Bordia, P., (2007), "Rumor Psychology: Social and Organizational Approaches", NY: American Psychological Association.

42. Doney P.M., Cannon J.P., (1997), "An examination of the nature of trust in buyer-seller relationships", Journal of Marketing, Vol.61, No.2.

43. Donovan, P., (2007), "How idle is idle talk? One hundred years of rumor research", Diogenes, Vol. 54, No. 1.

44. East, R., Hammond, K., \& Wright, M. (2007). The relative incidence of positive and negative word of mouth: A multi-category study. International Journal of Research in Marketing, 24(2), 175184.

45. East, R., Hammond, K., and Lomax, W., (2008), "Measuring the impact of positive and negative word of mouth on brand purchase probability", International journal of research in marketing, Vol. 25, No. 3.

46. El Naggar R. A. A., Bendary N., (2017), "The impact of experience and brand trust on brand loyalty, while considering the mediating effect of brand Equity dimensions, an empirical study on mobile operator subscribers in Egypt", The Business \& Management Review, Vol.9, No.2.

47. Erdem, T., \& Swait, J., (2004), "Brand credibility, brand consideration, and choice", Journal of Consumer Research, Vol. 31, No. 1.

48. Erics, A., Unal, S., Candan, F.B., Yildirim, H., (2012), "The effect of brand satisfaction, trust and brand commitment on loyalty and repurchase intentions", Procedia - Social and Behavioral Sciences, Vol. 58, No. 12 oct.

49. Escalas, J. E. \& Bettman, J. R., (2003), "You are what they eat: the influence of reference groups on consumers' connections to brands", Journal of Consumer Psychology, Vol. 13.

50. Esch, F-R., Langner, T., Schmitt, B. H. \& Geus, P., (2006), “Are brands forever? How brand knowledge and relationships affect 


\section{Dr. Sherif Taher Mohammed \& Dr. Sara Abd-El Fattah}

current and future purchases", Journal of Product \& Brand Management, Vol. 15, No. 2/3.

51. Fetscherin, M. \& Heinrich, D.,(2014), "Consumer brand relationships: A research landscape", Journal of Brand Management, Vol. 21, No. 5.

52. Fine, G., Campion-Vincent, V., \& Heath, C., (2005), "Rumor Mills: The social impact of rumor and legend" New Brunswick, NJ: Transaction Publishers.

53. Foroudi P., (2019), "Influence of brand signature, brand awareness, brand attitude, brand reputation on hotel industry's brand performance", International Journal of Hospitality Management, Vol.76.

54. Fournier S., (1998), "Consumers and their brands: developing relationship theory in consumer research", Journal of Consumer Research, Vol. 24, No. 4.

55. Fournier S., (2009), "Lessons learned about consumers' relationships with their brands", In MacInnis DJ, Park CW, Priester JR, Sharpe ME (Edn.) Handbook of Brand Relationships, pp. 7-23.

56. Fournier S., and Avery J., (2011), "Putting the "relationship" back into CRM", MIT Sloan Management Review, Vol. 52, No.3.

57. Garbarino E., Johnson M.S., (1999), "The different roles of satisfaction, trust, and commitment in customer relationships", Journal of Marketing, Vol.63, No.2.

58. Gheorghe, I. R. and Liao, M. N., (2012), "Investigating Romanian healthcare consumer behaviour in online communities: Qualitative research on negative eWOM", In Procedia - Social and Behavioural Sciences, Vol. 62.

59. Guo, C., (2015), "Exploring the Role of Perceived Word-of-Mouth Source Credibility and Brand Involvement in Online Negative Word-of-Mouth: An examination of Outcomes and Processes", $A$ Thesis in the John Molson School of Business, Presented in Partial Fulfillment of the Requirements for the Degree of Master of Science in, Administration at Concordia University Montreal, Quebec, Canada 
Scientific Journal for Financial and Commercial Studies and Researches (SJFCSR) Faculty of Commerce - Damietta University

60. Gurviez P., Korchia M., (2003), "Test of a consumer brand relationship model including trust and three consequences", Thirtieth International Research Seminar in Marketing.

61. Hair, J. F., Hult, G. T., Ringle, C. M., \& Sarstedt, M. (2017). A Primer on Partial Least Squares Structural Equation Modeling $(P L S-S E M)\left(2^{\text {nd }}\right.$ Ed. $)$. Los Angeles, CA: SAGE.

62. Hartman, K. B., Hunt, J. B., and Childers, C. Y., (2013), "Effects of eWOM valence: examining consumer choice using evaluations of teaching", Journal of Behavioral Studies in Business, Vol. 6, No. 1.

63. Hennig-Thurau, T., Gwinner, K. P., Walsh, G., \& Gremler, D. D., (2004), "Electronic word-of-mouth via consumer-opinion platforms: What motivates consumers to articulate themselves on the internet?", Journal of interactive marketing, Vol. 18, No.1.

64. Henseler, J., Ringle, C. M., \& Sarstedt, M. (2015). A New Criterion for Assessing Discriminant Validity in Variance-Based Structural Equation Modeling. Journal of the Academy of Marketing Science, 43(1), 115-135.

65. Hess, J., Story, J. \& Danes, J., (2011), "A three-stage model of consumer relationship investment.", Journal of Product \& Brand Management, Vol. 20, No. 1.

66. Hudson, S., Roth, M.S., Madden, T.J. \& Hudson, R., (2015), “The effects of social media on emotions, brand relationship quality and word of mouth: An empirical study of music festival attendees", Tourism Management, Vol. 47.

67. Jeong, E. H. and Jang, S., (2011), "Restaurant experiences triggering positive electronic word-of-mouth (eWOM) motivations", International Journal of Hospitality Management, Vol.30, No. 2.

68. Kabadayi E.T., Alan A.K., (2012), "Brand trust and brand affect: Their strategic importance on brand loyalty", Journal of Global Strategic Management, Vol.11, No. 6.

69. Kalamas, M., Laroche, M., \& Makdessian, L., (2008), "Reaching the boiling point: Consumers' negative affective reactions to firmattributed service failures", Journal of Business Research, Vol. 61, No. 8. 


\section{Dr. Sherif Taher Mohammed \& Dr. Sara Abd-El Fattah}

70. Kang, J., Tang, L. \& Fiore, A.M., (2014), "Enhancing consumerbrand relationships on restaurant Facebook fan pages: Maximizing consumer benefits and increasing active participation", International Journal of Hospitality Management, Vol. 36.

71. Keh, H. T. and Nguyen, M. T. T., (2007), "The Effects of Entrepreneurial Orientation and Marketing Information on the Performance of SMEs", Journal of Business Venturing, Vol. 22, No. 4.

72. Keller, K.L., (2001), "Building Customer-Based Brand Equity: ABlueprint for Creating Strong Brands", Boston, MA: Marketing Science Institute.

73. Kim, E. H., (2005), "The forming factors of long-term orientation in foodservice franchise system", International Journal of Tourism and Hospitality Research, Vol. 19, No. 3.

74. Kim, J. and Gupta, P., (2012), "Emotional expressions in online user reviews. How they influence consumers' product evaluations", Journal of Business Research, Vol.65, No. 7.

75. Kim, K., Park, J. \& Kim, J., (2013)," Consumer-brand relationship quality: When and how it helps brand extensions", Journal of Business Research, Vol. 67, No.4.

76. Kock, N. (2015). Common method bias in PLS-SEM: A full collinearity assessment approach. International Journal of ECollaboration, 11(4), 1-10. https://doi.org/10.4018/ijec.2015100101.

77. Kosfeld, M., (2005), "Rumors and markets", Journal of Mathematical Economics, Vol.41, No.6.

78. Krishnan H.S., (1996), "Characteristics of memory associations: A consumer-based brand equity perspective", International Journal of Research in Marketing, Vol.13, No.4.

79. Kumar, V., (2008), Managing Customers for Profit: Strategies to Increase Profits and Build Loyalty. Prentice Hall Professional, p. 193

80. Lee, H.J. \& Kang, M.S., (2013), "The effect of brand personality on brand relationship, attitude and purchase intention with a focus on brand community", Academy of Marketing Studies Journal, Vol. 17, No.2. 
Scientific Journal for Financial and Commercial Studies and Researches (SJFCSR) Faculty of Commerce - Damietta University

81. Leung, L. C., (2016), "The Role of Consumer Brand Experiences and Relationship in Contributing to Brand Equity for Services", Athens Journal of Business and Economics, Volume 2, No. 2

82. Lewis B.R., Soureli M., (2006), "The antecedents of consumer loyalty in retail banking". Journal of Consumer Behaviour: An International Research Review, Vol.5, No. 1.

83. Little, R. J., \& Rubin, D. B. (2019). Statistical analysis with missing data (Vol. 793). John Wiley \& Sons.

84. Liu, F., Burton-Jones, A., \& Xu, D., (2014), "Rumors on Social media in disasters: Extending Transmission to Retransmission", In PACIS, p. 49.

85. Loureiro, S.M.C., Ruediger, K.H. \& Demetris, V., (2012), "Brand emotional connection and loyalty", Journal of Brand Management, Vol. 20, No. 1.

86. Luk, S. T. K., \& Yip, L. S. C., (2008), "The moderator effect of monetary sales promotion on the relationship between brand trust and purchase behavior", Journal of Brand Management, Vol. 15, No. 6 .

87. Luureiro, S.M.C., (2015), "Loving and Hating Brands: Mulitiple Relationships between Consumers and Brands", Handbook of Research on Managing and Influencing Consumer Behavior (pp.417-438), chapter 18.

88. MacIinnis D. J., Park C. W., and Priester J., (2009), "Why brand relationships? ", In MacInnis DJ, Park CW, Priester JR, Sharpe ME (Edn.) Handbook of Brand Relationships, pp. ix-xxi.

89. Martin, W. C., and Lueg, J. E., (2013), "Modeling Word-of-Mouth Usage", Journal of Business Research, Vol. 66, No. 7

90. McAlexander, J.H., Schouten, J. W., \& Koening, H. F., (2002), "Building brand community" Journal of Marketing, Vol. 66, No. 1.

91. Miller, D. E., (1992), "Snakes in the greens" and rumor in the inner city”, The Social Science Journal, Vol. 29, No. 4. 


\section{Dr. Sherif Taher Mohammed \& Dr. Sara Abd-El Fattah}

92. Mohr, J., \& Nevin, J. R., (1990), "Communication strategies in marketing channels: A theoretical perspective", Journal of Marketing, Vol.54, No.4.

93. Moorman C., Zaltman G., and Deshpande R., (1992), "Relationships between providers and users of marketing research: The dynamics of trust within and between organizations", Journal of Marketing Research, Vol. 29, No. 3.

94. Moreira, A. C., Silva, P. M. F., and Moutinho, V. M. F., (2017), "The Effect of Brand Experiences on Quality, Satisfaction, and Loyalty: An Empirical Study in the Telecommunications MultiplePlay Service Market", Revista Innovar Journal, Vol. 27, No. 64.

95. Morgan R.M., Hunt S.D., (1994), "The commitment trust theory of relationship marketing", Journal of Marketing, Vol.58, No.3.

96. Ndubisi, N. O., (2007), "Relationship marketing and customer loyalty", Marketing Intelligence \& Planning, Vol. 25, No.1.

97. Nobre, H., (2011), "Should consumers be in love with brands? An investigation into the influence that specific consumer-brand relationships have on the quality of the bonds that consumers develop with brands", Journal of transnational management, Vol. 16, No. 4.

98. Oliver, RL 1999, 'Whence consumer loyalty?', Journal of Marketing, vol. 63, pp. 33-44.

99. Pantano, E. and Corvello, V., (2013), "The Impact of Experience on Companies' Reaction to Negative Comments on Social Media", Journal of Direct, Data and Digital Marketing, Vol. 14, No. 3.

100. Parasuraman, A., Zeithaml, V. A., \& Berry, L. L., (1985), “A conceptual model of service quality and its implications for future research", Journal of Marketing, Vol. 49, no. 4

101. Peterson, W. A., \& Gist, N. P. (1951). Rumor and public opinion. American Journal of Sociology, 159-167.

102. Petruzzellis, L., Winer, R. S., (2016), Rediscovering the Essentiality of Marketing, Proceedings of the 2015 Academy of Marketing Science (AMS) World Marketing Congress, Springer. p. 210 
Scientific Journal for Financial and Commercial Studies and Researches (SJFCSR) Faculty of Commerce - Damietta University

103. Pontevia, A., Arançoise, A., and Kimmel, A.J., (2008), "Negative word-ofmouth and redress strategies: An exploratory comparison of French and American managers", Journal of Consumer Satisfaction, Dissatisfaction and Complaining Behavior, Vol. 21.

104. Portal, S., Abratt, R., and Bendixen, M., (2019), "The Role of Brand Authenticity in Developing Brand Trust), Journal of Strategic Marketing, Vol. 27, No. 8

105. Prihandoko, D., (2016), "THE INFLUENCE OF BRAND RELATIONSHIP, BRAND SATISFACTION, AND PERCEIVED PRICE TOWARDS BRAND LOYALTY IN PT X'S CUSTOMER, INDONESIA", Journal The WINNERS, Vol. 17, No. 2,

106. Ramesh K.S., Advani J.Y., (2005), "Factors affecting brand loyalty: A study in an emerging market on fast moving consumer goods", Journal of Customer Behavior. Vol. 4, No.2.

107. Reast, J. D., (2005), "Brand trust and brand extension acceptance: The relationship", Journal of Product and Brand Management, Vol. 14, No. 1.

108. Rempel, J. K, Holmes, J.G. and Zanna, M.P., (1985), "Trust in Close Relationships", Journal of Personality and Social Psychology, Vol. 49, No. 1.

109. Richins, M. L., (1983), "Negative word-of-mouth by dissatisfied consumers: A pilot study", Journal of Marketing, Vol.47, No. 1.

110. Richins, M. L., (1984), "Word of mouth communication as negative information", NA-Advances in Consumer Research, Vol. 11 .

111. Rieke, M.L., and Guastello, S.J., (1995), "Unresolved issues in honesty and integrity testing", American Psychologist, Vol.50, No.6.

112. Ring P.S. and Van de Ven A.H., (1992), "Structuring Cooperative Relationships between Organizations", Strategic Management Journal, Vol.13, No. 7.

113. Robert, M.M. and Shelby, H.D., (1994), "The Commitment-Trust Theory of Relationships Marketing", Journal of Marketing, Vol.58, No. 3. 


\section{Dr. Sherif Taher Mohammed \& Dr. Sara Abd-El Fattah}

114. Rosenbaum-Elliott, R., Percy, L., Pervan, S., (2015), "Strategic Brand Management", Oxford University Press, p. 38.

115. Rosnow, R. L. and Kimmel, A. J., (2000), "Rumors," Encyclopedia of Psychology, Vol. 7.

116. Rosnow, R. L., (1980), "Psychology of Rumor Reconsidered," Psychological Bulletin, Vol.87, No. 3.

117. Rosnow, R. L., (1991), "Inside rumor: A personal journey", American Psychologist, Vol.46, No.5.

118. Rosnow, R. L., Esposito, J.L., and Gibney, L., (1988), "Factors Influencing Rumor Spreading: Replication and Extension," Language \& Communication, Vol. 8, No. 1.

119. Rossiter, JR, Percy, L \& Donovan, RJ 1991, 'A better advertising planning grid', Journal of Advertising Research, vol. 31, no. 5, pp. 11-21.

120. Sahin A., Zehir C., Kitapçı H., (2011), "The effects of brand experiences, trust and satisfaction on building brand loyalty; an empirical research on global brands", Procedia-Social and Behavioral Sciences, Vol. 24.

121. Sahin, A., and Zehir, C., (2012), "Does Brand Communication Increase Brand Trust? The Empirical Research on Global Mobile Phone Brands", Social and Behavioral Sciences, Vol. 58.

122. Schlosser, A. E., (2005), "Posting versus lurking: Communicating in a multiple audience context.", Journal of Consumer Research, Vol.32, No.2.

123. Septianto, F., Gavin Northey, G., Chiewc, T.M., Ngo, L.V., (2019), "Hubristic pride \& prejudice: The effects of hubristic pride on negative word-of-mouth", International Journal of Research in Marketing. Vol.11, No.3.

124. Shimp, T.A., and Madden, T.J., (1988), "Consumer-object relations: A conceptual framework based analogously on Sternberg's triangular theory of love", Advances in Consumer Research, Vol. 15, No. 1.

125. Shin, S.K.S., Amenuvor, F.E., Basilisco, R. and Owusu-Antwi, K., (2019), "Brand Trust and Brand Loyalty: A Moderation and 
Scientific Journal for Financial and Commercial Studies and Researches (SJFCSR) Faculty of Commerce - Damietta University

Mediation Perspective", Current Journal of Applied Science and Technology, Vol. 38, No. 4.

126. Sirdeshmukh D., Singh J., and Sabol B., (2002), "Consumer trust, value, and loyalty in relational exchanges", Journal of Marketing, Vol.66.

127. Smit E., Bronner F., and Tolboom M., (2007), "Brand relationship quality and its value for personal contact", Journal of Business Research, Vol. 60.

128. Soscia, I., (2007), "Gratitude, delight, or guilt: The role of consumers' emotions in predicting postconsumption behaviors", Psychology \& Marketing, Vol. 24, No.10.

129. Sreejesh, S \& Mohapatra, S 2014, Mixed method research design: An application in consumer-brand relationships (CBR), Springer, Berlin, Germany.

130. Suh, B. \& Han, I., (2003), "The Impact of Customer Trust and Perception of Security Control on the Acceptance of Electronic Commerce", International Journal of Electronic Commerce, Volume 7 No.3. 3 ., and Kuntaraporn, M., (2006), "Online Word-of-mouth (or mouse): An Exploration of Its Antecedents and Consequences", Journal of Computer-Mediated Communication, Vol.11, No.4.

132. Sung, Y., \& Kim, J., (2010), "Effects of brand personality on brand trust and brand affect", Psychology \& Marketing, Vol. 27, No. 7.

133. Sweeney, J. C., Soutar, G. N., and Mazzarol, T., (2005), "The difference between positive and negative word-of-mouth - emotion as a differentiator", in Proceedings of the ANZMAC 2005 Conference: Broadening the Boundaries), pp. 331-337.

134. Taber, K. S. (2018). The use of Cronbach's alpha when developing and reporting research instruments in science education. Research in Science Education, 48(6), 1273-1296.

135. Tasnim, S., Hossain, M.M., and Mazumder, H., (2020), "Impact of Rumors and Misinformation on COVID-19 in Social Media", Journal of Preventive Medicine and Public Health, Vol. 53. 


\section{Dr. Sherif Taher Mohammed \& Dr. Sara Abd-El Fattah}

136. Tenenhaus, M., Esposito Vinzi, V., Chatelinc, Y.-M. \& Lauro, C. (2005) PLS Path Modelling, Computational Statistics \& Data Analysis, 48 (1), 159-205.

137. Thomas, J. B., Peters, C. O., Howell, E. G., and Robbins, K., (2012), "Social media and negative word of mouth: strategies for handing unexpecting comments", Atlantic Marketing Journal, Vol. 1, No. 2.

138. Thorgjornsen, H., Supphellen,M., Nysveen, H. and PedersenP.E., (2002), "Building Brand Relationships Online: A Comparison of Two Interactive Applications", Journal of Interactive Marketing, Vol.16, No.3.

139. Valta, K.S., (2013), "Do relational norms matter in consumerbrand relationships?", Journal of Business Research, Vol. 66, No. 1.

140. van Griethuijsen, R. A., van Eijck, M. W., Haste, H., den Brok, P. J., Skinner, N. C., Mansour, N., ... \& BouJaoude, S. (2015). Global patterns in students' views of science and interest in science. Research in science education, 45(4), 581-603.

141. Veloutsou C., (2007), "Identifying the dimensions of the productbrand and consumer relationship", Journal of Marketing Management, Vol. 23, No. (1/2).

142. Verhoef P.C., Franses P.H., and Hoekstra J.C., (2002), "The effect of relational constructs on customer referrals and number of services purchased from a multiservice provider: does age of relationship matter?", Journal of the Academy of Marketing Science, Vol.30, No. 3.

143. Vosoughi, S., (2015), "Automatic detection and verification of rumors on Twitter", [Doctoral dissertation], Massachusetts Institute of Technology.

144. Wangenheim, F. V. (2005). Postswitching negative word of mouth. Journal of Service Research, 8(1), 67-78.

145. Weinberger, M. G., Allen,C., T., and Dillon, W. R., (1981), "The impact of negative marketing communications: The consumers union/Chrysler controversy", Journal of Advertising, Vol. 10, No. 4.

146. Wetzer, I. M., Zeelenberg, M., \& Pieters, R., (2007), "Never eat in that restaurant, I did!": Exploring why people engage in negative 
Scientific Journal for Financial and Commercial Studies and Researches (SJFCSR) Faculty of Commerce - Damietta University

word-of-mouth communication", Psychology \& Marketing, Vol. 24, No. 8.

147. Williams, M., and Buttle, F., (2014), "Managing negative wordof-mouth: an exploratory study", Journal of marketing management, Vol. 30, No. 13-14.

148. Yang, H. L. \& Wu, W.P., (2016), "THE EFFECTS OF CONSUMERS' BELIEF REGARDING INTERNET RUMORS ON PURCHASESE INTENTION FROM DIFFERENT SPREADING CHANNELS", International Journal of Information Systems Management Research \& Development, Vol. 6, No. 1.

149. Zehra S.J., Arshad U., (2019), "Brand trust And Image: Effect on customers' satisfaction", Journal of Marketing and Logistics, Vol. 2.

150. Zhang, W., \& Watts, S., (2004), "Knowledge adoption in online communities of practice", Systemes d'Information et Management, Vol.9, No.1.

151. Zhang, Y., Feick, L., \& Mittal, V., (2013), "How males and females differ in their likelihood of transmitting negative word of mouth", Journal of Consumer Research, Vol. 40, No.6.

152. Zubiaga, A., Liakata, M., Procter, R., Bontcheva, K., \& Tolmie, P., (2015), "Towards detecting rumors in socialmedia", Association for the Advancement of Artificial Intelligence, p.p. 35-41. 
Dr. Sherif Taher Mohammed \& Dr. Sara Abd-El Fattah

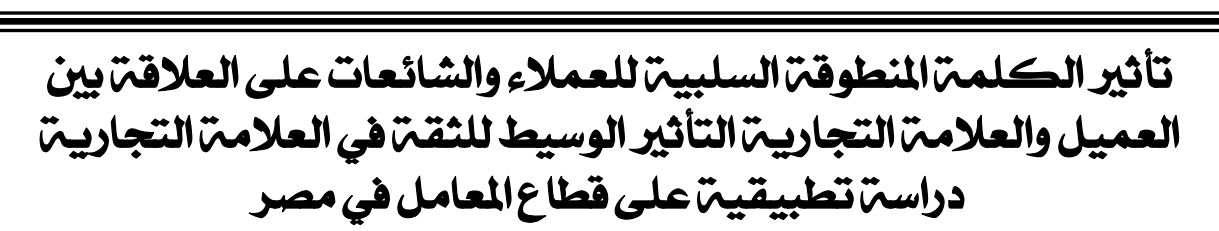

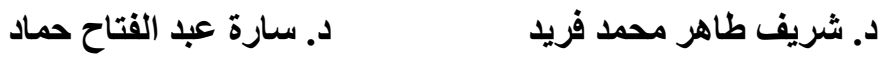

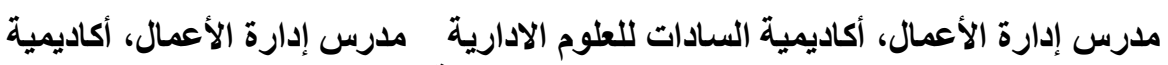 \\ السادات للعلوم الادارية الادابة
}

Sherif-taher@hotmail.com

الملفصص:

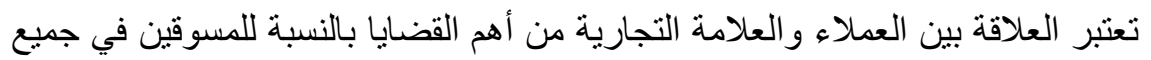

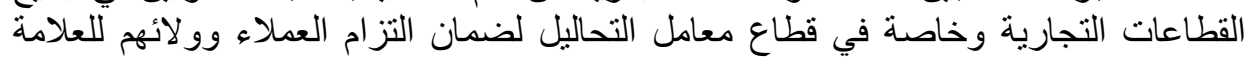

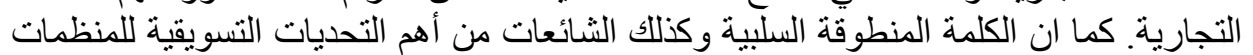

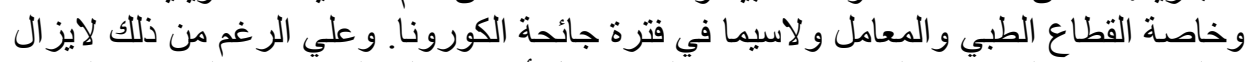

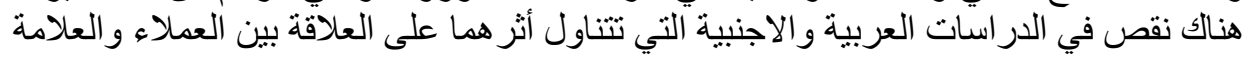

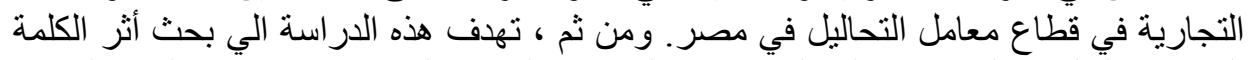

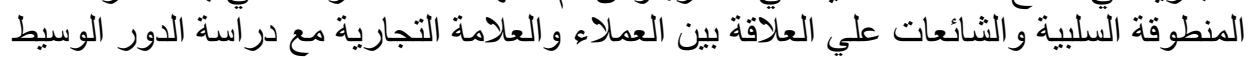

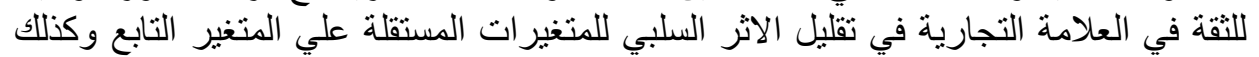

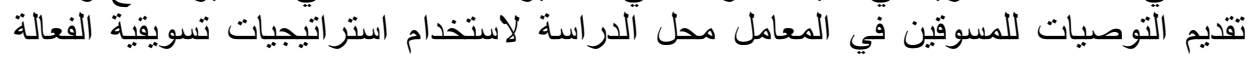

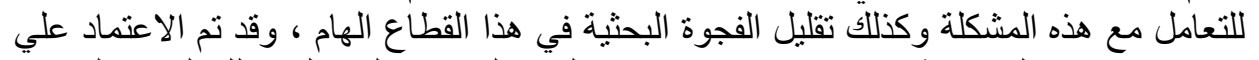

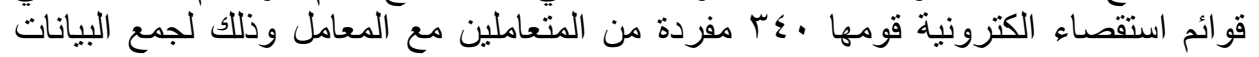

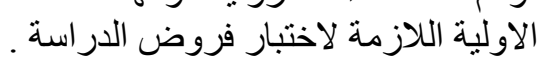

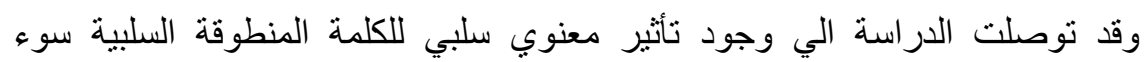

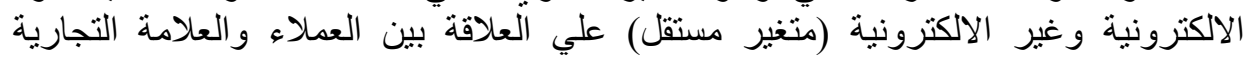

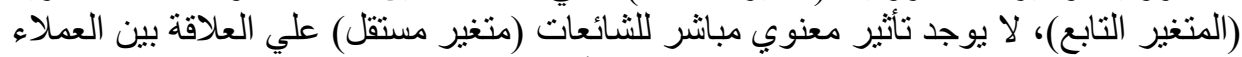

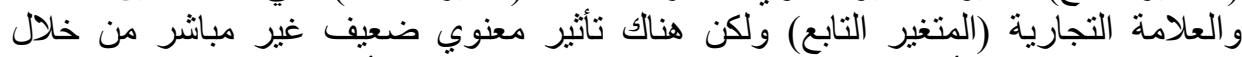

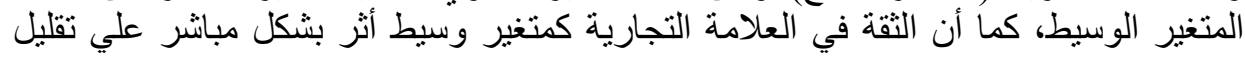

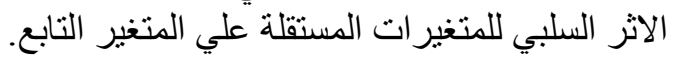

الكلمات الدالت المفتاحيتّ: الكلمة المنطوقة السلبية للعملاء، الثائعات، العلاقة بين العميل و العلامة التجارية، التقة في العلامة التجارية، التماتية قطاع معامل التحاليل 